\title{
Spatial Distributions of Surface Sedimentary Organics and Sediment Profile Image Characteristics in a High-Energy Temperate Marine RiOMar: The West Gironde Mud Patch
}

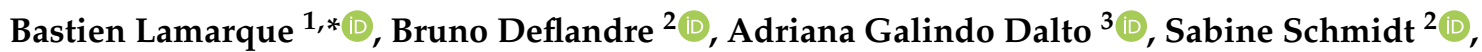 \\ Alicia Romero-Ramirez ${ }^{1}$, Frédéric Garabetian ${ }^{1}$, Nicolas Dubosq ${ }^{2}{ }^{\circledR}$, Mélanie Diaz ${ }^{2}{ }^{\circledR}$, Florent Grasso ${ }^{4}{ }^{\oplus}$, \\ Aldo Sottolichio ${ }^{2}$, Guillaume Bernard ${ }^{1}{ }^{(}$, Hervé Gillet ${ }^{2}$, Marie-Ange Cordier ${ }^{2}$, Dominique Poirier ${ }^{2}$, \\ Pascal Lebleu $^{2,+}{ }^{+}$, Hervé Derriennic ${ }^{2}$, Martin Danilo ${ }^{2}$, Márcio Murilo Barboza Tenório ${ }^{3}{ }^{10}$ and Antoine Grémare ${ }^{1}$
}

check for updates

Citation: Lamarque, B.; Deflandre,

B.; Galindo Dalto, A.; Schmidt, S.;

Romero-Ramirez, A.; Garabetian, F.; Dubosq, N.; Diaz, M.; Grasso, F.;

Sottolichio, A.; et al. Spatial

Distributions of Surface Sedimentary

Organics and Sediment Profile Image

Characteristics in a High-Energy

Temperate Marine RiOMar: The West

Gironde Mud Patch. J. Mar. Sci. Eng.

2021, 9, 242. https://doi.org/

$10.3390 /$ jmse 9030242

Academic Editor: Antoni Calafat

Received: 14 December 2020

Accepted: 2 February 2021

Published: 24 February 2021

Publisher's Note: MDPI stays neutral with regard to jurisdictional claims in published maps and institutional affiliations.

Copyright: (c) 2021 by the authors Licensee MDPI, Basel, Switzerland. This article is an open access article distributed under the terms and conditions of the Creative Commons Attribution (CC BY) license (https:// creativecommons.org/licenses/by/ $4.0 /)$
1 UMR EPOC, Université de Bordeaux, CNRS, UMR 5805, Station Marine d'Arcachon, 2 rue du Professeur Jolyet, 33120 Arcachon, France; alicia.romero-ramirez@u-bordeaux.fr (A.R.-R.); frederic.garabetian@u-bordeaux.fr (F.G.); guillaume.bernard@u-bordeaux.fr (G.B.); antoine.gremare@u-bordeaux.fr (A.G.)

2 UMR EPOC, Université de Bordeaux, CNRS, UMR 5805, Bâtiments B18/B18N, Allée Geoffroy Saint-Hilaire, CEDEX, 33615 Pessac, France; bruno.deflandre@u-bordeaux.fr (B.D.); sabine.schmidt@u-bordeaux.fr (S.S.); nicolas.dubosq@u-bordeaux.fr (N.D.); melanie.diaz@u-bordeaux.fr (M.D.); aldo.sottolichio@u-bordeaux.fr (A.S.); herve.gillet@u-bordeaux.fr (H.G.); marie-ange.cordier@u-bordeaux.fr (M.-A.C.); dominique.poirier@u-bordeaux.fr (D.P.); pascal.lebleu@u-bordeaux.fr (P.L.); herve.derriennic@u-bordeaux.fr (H.D.); martin.danilo@u-bordeaux.fr (M.D.)

3 Departamento de Biologia Marinha, Instituto de Biologia, Universidade Federal do Rio de Janeiro, Rio de Janeiro CEP 21941-902, Brazil; agdalto@gmail.com (A.G.D.); mbtenorio@hotmail.com (M.M.B.T.)

4 IFREMER Brest-DYNECO/DHYSED, Centre de Bretagne, CS 10070, 29280 Plouzané, France; florent.grasso@ifremer.fr

* Correspondence: bastien.lamarque@u-bordeaux.fr

+ Deceased.

Abstract: The spatial distributions of (1) surface sediment characteristics $\left(\mathrm{D}_{0.5}\right.$, Sediment Surface Area (SSA), Particulate Organic Carbon (POC), Chlorophyll- $a$ (Chl- $a$ ), Phaeophytin- $a$ (Phaeo- $a$ ), Total and Enzymatically Hydrolyzable Amino Acids (THAA, EHAA), $\delta^{13} \mathrm{C}$ ) and (2) sediment profile image (apparent Redox Potential Discontinuity (aRPD), numbers and depths of biological traces) characteristics were quantified based on the sampling of 32 stations located within the West Gironde Mud Patch (Bay of Biscay, NE Atlantic) in view of (1) assessing the spatial structuration of a temperate river-dominated ocean margin located in a high-energy area, (2) disentangling the impacts of hydrodynamics and bottom trawling on this structuration, and (3) comparing the West Gironde Mud Patch with the Rhône River Prodelta (located in a low-energy area). Results support the subdivision of the West Gironde Mud Patch in a proximal and a distal part and show (1) the existence of depth gradients in surface sedimentary organics characteristics and bioturbation within the distal part; (2) no evidence for a significant effect of bottom trawling, as opposed to Bottom Shear Stress, on the West Gironde Mud Patch spatial structuration; and (3) major discrepancies between spatial structuration in the West Gironde Mud Patch and the Rhône River Prodelta, which were attributed to differences in tidal regimes, sedimentation processes, and local hydrodynamics, which is in agreement with current river-dominated ocean margin typologies.

Keywords: RiOMar; surface sediment; spatial distribution; sedimentary organics; bioturbation

\section{Introduction}

Continental margins are the interface between land and the open ocean, where 50 to $80 \%$ of continental Particulate Organic Carbon (POC) inputs are mineralized [1-3]. Less than $5 \%$ of these inputs are transferred to the deep ocean [4], the remaining part 
being buried in continental margin sediments. River-dominated ocean margins (RiOMars), defined as margins impacted by major rivers freshwater and/or sediment discharges (e.g., plumes of Amazon, Yangtze or Mississippi Rivers), are the main marine primary depositional areas of riverine particulate continental inputs [2,5]. They account for 40 to $50 \%$ of continental POC burial occurring in continental margins $[2,3,6]$. Burial is tightly cued by biogeochemical processes taking place at the water-sediment interface $[3,5,7]$. Therefore, assessments of the structuration and functioning of the benthic components of marine RiOMars are key issues to reach a comprehensive understanding of the marine contribution to global biogeochemical cycles $[1,3]$.

Benthic macrofauna plays a major role in the biogeochemistry of the top centimeters of the sediment column through bioturbation (i.e., sediment mixing and bioirrigation [8]). This includes both changes in the spatial distribution and the temporal dynamics of electron acceptors, which influence mineralization fluxes [9-11]. Mostly based on the analysis of macrofauna vertical distribution within the sediment column and X-rays radiographies, Rhoads et al. [12] first proposed a conceptual model describing the response of macrofauna and surface sediments to the inputs of major rivers. According to this model, macrofauna spatial distribution is mainly determined by (1) physical disturbance induced by intense continental inputs, and (2) reduction in Particulate Organic Matter (POM) availability due to the limitation of primary production in turbid river plumes. In proximal (i.e., the closest to the river mouth) parts of RiOMars, high and irregular sedimentation rates induce sedimentary instability, precluding the establishment of mature macrobenthic communities. Moreover, high turbidity limits primary production and results in mainly low (and refractory) POM concentrations in surface sediments. Accordingly, RiOMar proximal areas are characterized by low bioturbation intensities and low mineralization fluxes. Conversely, in distal (i.e., deeper) parts, sedimentation is lower and primary production is higher, allowing for the establishment of mature macrobenthic communities, high bioturbation intensities, and mineralization fluxes.

Several studies have compared RiOMars based on either the characterization/quantification of geomorphological [5] or biogeochemical [3] processes. Their results highlighted the major effect of energetic regimes on RiOMar morphologies [5] and POC mineralization/burial intensities [3]. This later study drew a clear distinction between (1) low-energy systems, with both significant sedimentation rates and carbon preservation (later referred as type 1), and (2) high-energy tidal and/or wave systems with both high sediment oxygenation and low carbon preservation rates (later referred as type 2). It evidenced that the spatial distributions of the benthic components of RiOMars are cued by both riverine inputs and marine hydrodynamics. This categorization was mostly based on tropical/subtropical systems, the Rhône River being the only major (type 1) considered temperate RiOMar. Moreover, both studies considered RiOMars and their continuity with fluvial systems in their entirety, even though McKee et al. [5] underlined the interest of differencing RIOMAR sub-environments and comparing RiOMar types. Thus, there is still a clear need to document the spatial structuration of a potential temperate type 2 RiOMar and to compare it with a temperate type 1 one.

Together with the bottom shear stress induced by both waves and bottom currents, bottom trawling is contributing to control sediment resuspension in coastal areas [13-20]. As such, it can deeply affect surface sediments, benthic macrofauna and bioturbation [13,21-24]. RiOMar mud fields are organically enriched as compared to surrounding sediments and often constitute preferential fishing areas [19,20]. Therefore, it is also important to unravel the role of both hydrodynamics and bottom trawling in controlling the structuration of benthic ecosystems in RiOMars.

The present study is aiming at (1) improving current knowledge regarding the spatial structuration of a potential temperate type $2 \mathrm{RiOMar}$, (2) disentangling the potential effects of hydrodynamics and bottom trawling in controlling this structuration, and (3) comparing this spatial structuration with the one of a type 1 temperate RiOMar (i.e., the Rhône River Prodelta [3]). It is based on the synoptic sampling of a large number of stations and 
the quantitative analysis of (1) surface sediment characteristics and (2) Sediment Profile Images (SPI).

\section{Materials and Methods}

\subsection{The West Gironde Mud Patch}

The West Gironde Mud Patch (WGMP) is a $420 \mathrm{~km}^{2}$ sedimentary body located in the Bay of Biscay $40 \mathrm{~km}$ off the Mouth of the Gironde Estuary (Figure 1). This relict paleovalley/depression constitutes the primary depocenter (sedimentation rates between less than 1 and $5 \mathrm{~mm} \cdot \mathrm{y}^{-1}[25,26]$ ) of fine particles originating from the Gironde Estuary, which presents an annual mean water discharge of $944 \mathrm{~m}^{3} \cdot \mathrm{s}^{-1}$ [27] and daily discharge up to $7500 \mathrm{~m}^{3} \cdot \mathrm{s}^{-1}$ during wintertime [28]. The WGMP is located in a macro-tidal environment with a tidal range from 1.5 to $5 \mathrm{~m}$ [26,29]. The continental shelf around the Mouth of the Gironde Estuary is dominated by strong swells/waves, which can reach maximal amplitudes of $15 \mathrm{~m}$ and time periods of $15 \mathrm{~s}$ during winter storms [30]. These hydrological conditions prevent the sedimentation of fine particles in the immediate vicinity of the Mouth of the Estuary. Therefore, the WGMP can a priori be considered as a potential temperate type 2 RiOMar [5]. The sedimentology of the WGMP has been extensively studied based on stratigraphic sequences, palynological data, $\mathrm{X}$-rays radiographies, and radiochronographies $[25,26,31-43]$. Sedimentological surveys have attributed a major role to hydrodynamics in controlling the spatial structuration of the WGMP [25,26,35,38,42]. This paradigm was based on both (1) the segmentation between a proximal and a distal part with no modern persistent sedimentation in the former due to strong hydrodynamics, and (2) the decreasing frequency of occurrence of vertical erosional sequences within the sediment column with station depth. The occurrence of spatial zonation in the distal part has also been addressed $[25,26,35,38,42]$ but without reaching a clear conclusion due to a limited number of sampled stations and to the lack of a fine quantitative assessment of bioturbation. Benthic macrofauna composition and associated biogeochemical processes have been largely neglected as well, with only two studies based on the sampling of a limited number of stations [44,45]. The WGMP is a preferential fishing area [46] where several benthic species are commercially exploited, including the Norway lobster (Nephrops norvegicus) and the common sole (Solea solea). Bottom trawls are commonly deployed in the area [46], and it has been suggested that their use may constitute a significant source of disturbance for benthic habitats [26,38,47]. Based on Vessel Monitoring System data, Mengual et al. $[19,20]$ showed that the Benthic Trawling Effort (BTE) in the WGMP can be locally intense (up to 10 times trawled $\cdot y^{-1}$ ) and seems to increase with depth.

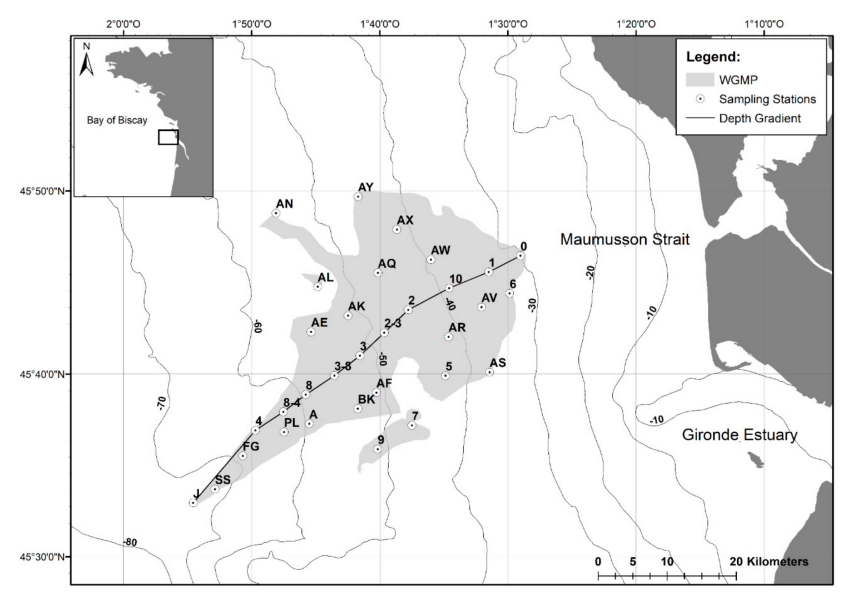

Figure 1. Map showing the location of the West Gironde Mud Patch along the French Atlantic coast, the locations of the 32 sampled stations, and the depth gradient sampled for X-ray radiographies and amino acids. The delimitation of the West Gironde Mud Patch (WGMP) is based on the acoustic measurements achieved during the JERICOBENT-5-TH cruise [48] and the surface sediment granulometry assessed during the present study [49]. 


\subsection{Sampling of Surface Sediment and Sediment Profile Images}

This study is based on samples collected during the JERICOBENT-5 cruise [49], which took place in June 2018 on board of the R/V Côtes de la Manche. Thirty-two stations located between 32.5 and $78 \mathrm{~m}$ depth, and allowing for a full coverage of the WGMP were sampled for both surface sediment characteristics and Sediment Profile Images (SPIs; Figure 1, Table A1). At each station, a sediment core (10 cm internal diameter) was collected using an Uwitec $^{\circledR}$ (Mondsee, Austria) monotube-corer. The upper top centimeter (i.e., $0-1 \mathrm{~cm}$ depth layer) was carefully extruded and split in two subsamples immediately frozen $\left(-20^{\circ} \mathrm{C}\right)$ for further analyses of (1) grain size, Sediment Surface Area (SSA; [50]), Particulate Organic Carbon (POC), and OC isotopic ratio; and (2) chloropigments. Total and Enzymatically Hydrolyzable Amino Acids (THAA and EHAA) were assayed at 11 stations distributed along a depth gradient (see Figure 1). At these stations, a second core was collected for $X$-rays radiographies (SCOPIX system; [51]). EHAA were not assayed at station J due to a technical problem. At all stations, between 4 and 8 SPIs were taken (at stations PL and $\mathrm{J}$, respectively) using a sediment profile imager (Ocean Imaging Systems ${ }^{\circledR}$, Pocasset, MA, USA) [52] fitted with a D7100 camera (Nikon ${ }^{\circledR}$, Tokyo, Japan).

\subsection{Analysis of Surface Sediment Characteristics}

Grain size was measured on duplicated aliquots of each sediment sample using a Master Sizer laser microgranulometer (Malvern Panalytical ${ }^{\circledR}$, Malvern, UK), which allowed for the computation of median diameter $\left(\mathrm{D}_{0.5}\right)$. SSAs were measured on freeze-dried sediments, previously degassed overnight at $150{ }^{\circ} \mathrm{C}$, using a Gemini VII 2390 Series Surface Area Analyzer (Micromeritics ${ }^{\circledR}$, Norcross, GA, USA) with the multi-point Brunauer-Emmett-Teller method [50]. POC was assayed using a LECO ${ }^{\circledR}$ (St. Joseph, MI, USA) CS 200 analyzer, after $2 \mathrm{M} \mathrm{HCl}$ overnight decarbonatation of previously freeze-dried sediments [53].

THAA and EHAA were analyzed on duplicates. THAA were extracted by acid hydrolysis. EHAA were extracted following the biomimetic approach proposed by Mayer et al. [54]. THAA and EHAA were analyzed by derivation to form fluorescent amino compounds with the presence of the thiol 3-mercaptopropionic acid (MPA). Fluorescent derivatives were separated by reverse-phase High-Performance Liquid Chromatography (Agilent ${ }^{\circledR}$, Santa Clara, CA, USA; 1260 INFINITY model) on a Phenomenex ${ }^{\circledR}$ (Torrance, CA, USA) Kinetex $5 \mu \mathrm{m}$ EVO C18 column using non-linear gradient of methanol-acetate buffer $(\mathrm{pH}=7,40 \mathrm{mM})$, and detected by fluorescence from 340 to $450 \mathrm{~nm}$ using an excitation wavelength of $338 \mathrm{~nm}$. The EHAA/THAA ratio was used as a lability index of bulk sedimentary organics [55-57].

Chlorophyll- $a$ (Chl- $a$ ) and Phaeophytin- $a$ (Phaeo- $a$ ) were assayed on thawed frozen $\left(-20^{\circ} \mathrm{C}\right)$ sediment after overnight acetone extraction (90\% final concentration) using a Perkin Elmer ${ }^{\circledR}$ LS-55 spectrofluorometer following Neveux and Lantoine [58]. Pigment data are lacking for station BK due to sample loss. All organic concentrations were normalized for SSA (i.e., expressed in terms of mass per SSA). The Chl- $a /(\mathrm{Chl}-a+$ Phaeo- $a$ ) ratio was used as a lability index of vegetal biomass $[55,56]$.

For the analysis of OC isotopic ratio, replicated freeze-dried sediment samples were decarbonated $(1 \mathrm{M} \mathrm{HCl})$ and later analyzed using a Thermo Scientific ${ }^{\circledR}$ Delta V plus IRMS coupled with a Thermo Scientific ${ }^{\circledR}$ (Waltham, MA, USA) Flash 2000 EA. Raw measurements were converted in usual $\delta^{13} \mathrm{C}$ units [59].

\subsection{Analysis of Sediment Profile Images}

Individual SPI were analyzed for (1) apparent Redox Potential Discontinuity (aRPD) thickness, (2) numbers of biogenic structures (tubes, burrows, oxic voids, feeding pits), (3) numbers of epi- and infauna, and (4) maximal depths of oxic voids within the sediment column. For the stations presenting a surface sandy layer, the upper limit for the computation of aRPD thickness was set below the transient top coarser sediment layer. Image analyses were achieved using the SpiArcBase software [60] and mean values and standard deviations were computed for each station. In addition, all SPIs were visually inspected for 
the presence of potential traces of bottom trawling. This included the presence of clasts and furrows [61,62], and of a surface puzzle fabric [63].

\subsection{Spatial Distribution of Bottom Shear Stress and Trawling Effort}

The spatial distribution of Bottom Shear Stress (BSS) was computed from a tridimensional numerical model deployed and validated over the study area [64]. This model, stretching from the Gironde Estuary to the continental shelf, is based on the MARS3D hydrodynamic model [65] and the WAVE WATCH III ${ }^{\circledR}$ wave model [66]. Its curvilinear mesh resolution is approximately $0.5 \times 0.5 \mathrm{~km}^{2}$ over the WGMP. The model integrates realistic hydro-meteorological forcing (i.e., wind, tide, surge, and river flow). BSS was computed as the combination of current-induced and wave-induced components following Soulsby's formulation [67]. A more detailed description of the model can be found in Grasso et al. [68]. Simulations achieved during the present study provided hourly outputs over the whole year preceding the JERICOBENT-5 cruise. In order to account for intense hydrodynamic events, 95th percentiles were used to characterize BSS intensities.

The spatial distribution of Bottom Trawling Effort (BTE), within and around the WGMP, was assessed based on vessel Automatic Identification System (AIS) data collected by Global Fishing Watch $[69,70]$. Raw (daily) BTE were available with a 1/100 degree (corresponding to $1.77 \mathrm{~km}^{2}$ cells) spatial resolution. For each cell, daily BTE were summed over the whole year preceding the JERICOBENT- 5 cruise. Summed BTE were expressed both in terms of $\mathrm{h} \cdot \mathrm{km}^{-2} \cdot \mathrm{y}^{-1}$ and number of times trawled $\cdot \mathrm{y}^{-1}$. The conversion between these two units was achieved following Mengual et al. [19,20].

\subsection{Analysis of WGMP Data}

2.6.1. Sediment Characteristics and Sediment Profile Images

For both sediment (i.e., SSA, POC, Chl- $a$, Phaeo- $a$, Chl- $a /(\mathrm{Chl}-a+$ Phaeo- $a$ ) ratio and $\delta^{13} \mathrm{C}$ ) and SPI (i.e., aRPD thickness; maximal oxic void depth; mean numbers of tubes, burrows, oxic voids, feeding structures, epifauna and infauna) characteristics, hierarchical clustering (Euclidean distance and average group linking) and Principal Components Analyses (PCAs) were used to define groups of stations and to assess relationships between variables. THAA, EHAA, and EHAA/THAA ratios were not included, since data were missing at some stations. Station depth, BSS, and BTE were introduced as supplementary variables in both PCAs. SIMilarity PROFile procedures (SIMPROF; [71]) were used to test for the statistical significance of differences between station groups resulting from hierarchical clustering. SIMilarity PERcentage analysis (SIMPER; [72]) was used to identify the SPI characteristics contributing the most to between-group differences. All analyses were run on normalized data using the PRIMER ${ }^{\circledR} 6$ software package [73].

Multivariate analyses supported the distinction between a proximal and a distal part in the WGMP (see Section 4.1). Simple linear regression models were used to assess the significance of the relationships between station depth and both surface sediment and SPI characteristics in the whole WGMP and in the sole distal part to avoid confounding effects resulting from (1) the high between-station variability in the proximal part and (2) major differences in sediment and SPI characteristics between parts. The same approach was used to assess the significance of the relationships between station depths and their coordinates on the first component of both PCAs.

\subsubsection{Bottom Shear Stress and Trawling Effort}

BSS 95th percentiles and summed BTE were mapped using the ArcGIS Desktop ${ }^{\circledR}$ 10.6 software. The relationships between BSS 95th percentiles, summed BTE within cells containing sampled stations, and (1) station depth, (2) surface sediment characteristics, and (3) SPI characteristics were assessed using simple linear regression models at the scale of the whole WGMP and/or its sole distal part. Multiple linear regression models were used to test for additive effects of BSS and BTE. 


\subsection{Comparisons with the Rhône River Prodelta}

The Rhône River Prodelta (RRP) is a ca $265 \mathrm{~km}^{2}$ [74] depositional system, located in the Gulf of Lions (North Mediterranea Sea). It is supplied with particles from the Rhône River, which presents a mean annual water discharge of $1700 \mathrm{~m} \cdot \mathrm{s}^{-1}$ and massive flood events (i.e., up to $11,000 \mathrm{~m}^{3} \cdot \mathrm{s}^{-1}$; [75]). The RRP is located in an environment with micro-tidal conditions (i.e., maximal tidal range of $0.4-0.5 \mathrm{~m}$ ) and wave mean heights of 1-1.5 $\mathrm{m}$ [76]. During winter storms, wave heights can exceptionally reach 3-4 m, with periods of about $6-7 \mathrm{~s}[77,78]$. These conditions allow for the sedimentation of fine particles at the immediate vicinity of the river mouth. Sedimentation rates are about $40 \mathrm{~cm} \cdot \mathrm{y}^{-1}$ in the proximal part (i.e., 5-30 m depth) of the RRP and between 1 and $10 \mathrm{~cm} \cdot \mathrm{y}^{-1}$ in its distal part (30-100 m depth; $[74,79,80])$. According to the classifications established by McKee et al. [5] and Blair and Aller [3], the RRP therefore constitutes a low-energy (type 1) temperate RiOMar in direct continuity with the Rhône River.

WGMP results collected during the present study were compared with those originating from the Chaccra cruise (April 2007), which took place in a comparable situation in terms of river flows [56] and during which the same parameters (i.e., $\mathrm{D}_{0.5}, \mathrm{POC}$, chloropigments, THAA, EHAA, $\delta^{13} \mathrm{C}$, and SPI characteristics) were measured at 7-10 stations located in the RRP $[56,81,82]$. Since modern sedimentation was shown to be restricted to the distal part of the WGMP (see above), the comparison was achieved between the sole WGMP distal part and the whole RRP. All organic concentrations were expressed in terms of sediment DW (eventually standardized for $\mathrm{D}_{0.5}$ ), since no SSA data were available for the RRP. For the same reason, we used mean instead of maximal oxic void depth. Mean values of WGMP and RRP characteristics were compared using one-way ANOVAs.

\section{Results}

\subsection{Surface Sediment Characteristics}

Except for two stations (i.e., stations 0 and 10), all particle size distributions were unimodal. There were marked differences in surface median sediment grain size $\left(D_{0.5}\right)$ among shallow stations (Figure 2A). $\mathrm{D}_{0.5}$ was minimal at station AV $(13.5 \mu \mathrm{m})$ and maximal at station $0(64.6 \mu \mathrm{m})$. Conversely, deep stations featured a narrower range (i.e., between 14.9 and $24.8 \mu \mathrm{m}$ at stations 7 and 2, respectively) of $\mathrm{D}_{0.5}$. Sediment Surface Area (SSA) was also more dispersed at shallow stations (i.e., between 3.4 and $14.2 \mathrm{~m}^{2} \cdot \mathrm{gDW}^{-1}$ at stations $\mathrm{AW}$ and $\mathrm{AV}$, respectively) (Figure $2 \mathrm{~B}$ ) than at deep stations (i.e., between 6.1 and $9.8 \mathrm{~m}^{2} \cdot \mathrm{gDW}^{-1}$ at stations 2 and 4 , respectively).
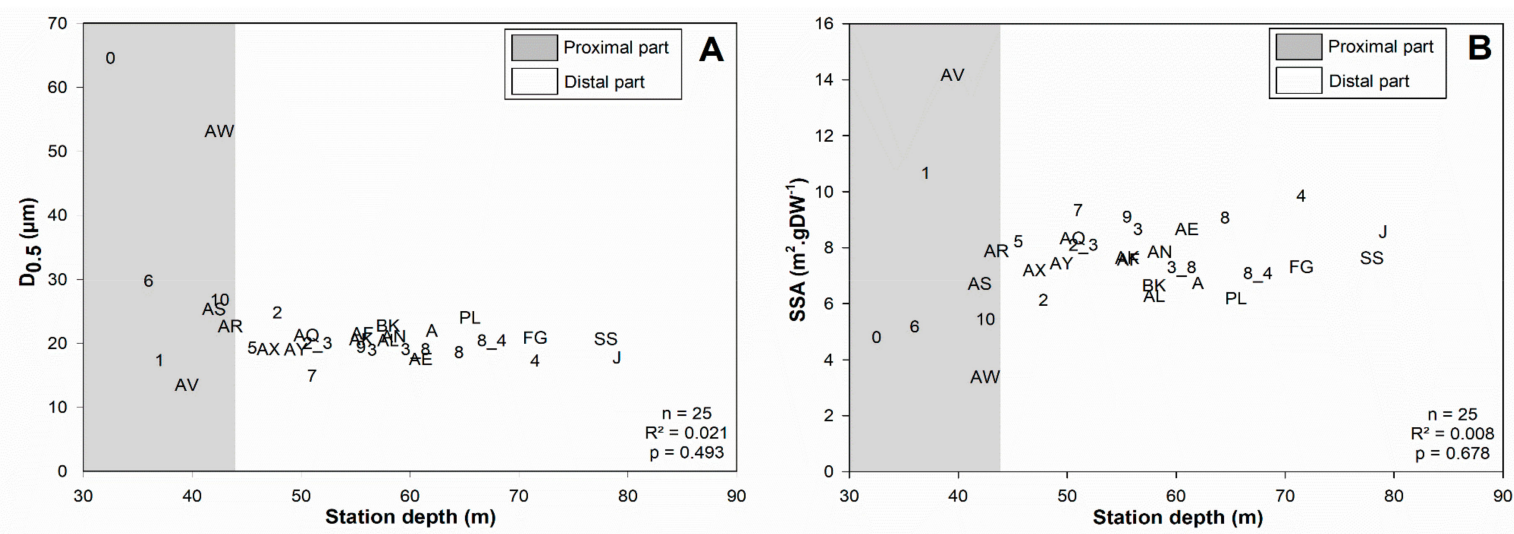

Figure 2. Relationships between station depth and: $\mathrm{D}_{0.5}(\mathbf{A})$; Sediment Surface Area (SSA; (B)). Gray areas represent the proximal part $(\mathrm{z}<42.5 \mathrm{~m})$ of the WGMP. Station codes are the same as in Figure 1 and Table A1. Statistical results refer to the sole WGMP distal part.

At the scale of the whole WGMP, SSA significantly decreased with increasing $\mathrm{D}_{0.5}$ following an exponential model $\left(\mathrm{y}=4.268+51.982 \times \mathrm{e}^{-0.134 \mathrm{x}} ; \mathrm{n}=32, \mathrm{R}^{2}=0.830\right.$, 
$p<0.001) . \mathrm{D}_{0.5}$, all surface sediment organic concentrations and Chl- $a /(\mathrm{Chl}-a+$ Phaeo- $a)$ ratio (Table A1) correlated significantly with station depth, which was not the case for SSA and $\delta^{13} C$ (Table A2). When considering only the distal part (see Section 4.1 for the delimitation between the proximal and distal parts), the correlations between station depth, $\mathrm{D}_{0.5}$, Chl- $a$, and Chl- $a$ /(Chl- $a+$ Phaeo- $a$ ) were not significant (Table A2).

Particulate Organic Carbon (POC) concentrations were between 0.50 and $2.06 \mathrm{mg} \cdot \mathrm{m}^{-2}$ at stations AV and J, respectively. POC correlated positively with depth in the distal part of the West Gironde Mud Patch (WGMP; Figure 3A, Table A2). Total Hydrolyzable Amino Acid (THAA) concentrations were between 0.18 and $0.69 \mathrm{mg} \cdot \mathrm{m}^{-2}$ at stations 10 and J respectively (Table A1). THAA correlated positively with station depth in both the whole WGMP and the distal part of the WGMP (Table A2). Enzymatically Hydrolyzable Amino Acids (EHAA) concentrations also correlated significantly with station depth at the scale of the whole WGMP, with values ranging from $0.047 \mathrm{mg} \cdot \mathrm{m}^{-2}$ (station 10) to $0.109 \mathrm{mg} \cdot \mathrm{m}^{-2}$ (stations 8-4). However, this correlation was not significant in the sole distal part. EHAA/THAA ratios ranged from 15.5 (station 8) to 26.6\% (station 10) (Table A1). They did not significantly correlate with station depth when considering either the whole WGMP or its sole distal part (Table A2). Stations AN and 3_8 constituted clear outliers (i.e., featuring high ratios as regard to their depth) in the relationship linking station depth and Chl- $a$ /(Chl- $a+$ Phaeo- $a$ ) ratio (Figure 3B). When excluding these two stations, this relationship was significantly negative in the distal part of the WGMP (Table A2). $\delta^{13} \mathrm{C}$ values presented a narrow variation range with values from $-23.66 \%$ to $-22.20 \%$ at stations 1 and 6, respectively. Variability relative to station depth was more marked in the proximal than in the distal part of the WGMP, where all $\delta^{13} \mathrm{C}$ values were around $-23 \%$ o (Figure 3C).

The first two components of the Principal Component Analysis (PCA) based on surface sediment characteristics accounted for $64.5 \%$ (i.e., $40.2 \%$ and $24.3 \%$ for the first and the second principal component, respectively) of the total variance (Figure 4A). The first component was defined by organic concentrations. The second component was mostly driven by the opposition between Chl- $a$ /(Chl- $a+$ Phaeo- $a$ ) ratio and $\delta^{13} \mathrm{C}$ on one side, and SSA on the other side (Figure 4B). Hierarchical clustering and the associated SIMPROF procedure resulted in the identification of 5 groups and 3 "isolated" stations (Figure 4A). Stations of group I, together with stations 1, 6, and AV, were all shallow (i.e., from 32.5 to $42.5 \mathrm{~m}$ depth). Group II was mostly composed of stations from the median part of the WGMP (i.e., from 43.5 to $60.5 \mathrm{~m}$ depth) except for stations AE, 8, 8-4, and 4, which were deeper (i.e., 31, 64.5, 67.5, and $71.5 \mathrm{~m}$, respectively). Group III was composed of deep stations (i.e., from 62 to $79 \mathrm{~m}$ depth) except for station AX $(z=47.0 \mathrm{~m})$. Stations of group IV (i.e., FG and PL) constituted apparent outliers to this overall pattern mostly due to their low Chl- $a$ / (Chl- $a+$ Phaeo- $a$ ) ratios and $\delta^{13} \mathrm{C}$ values compared to other deep stations. Likewise, stations of group V (i.e., $\mathrm{AN}$ and 3-8) differed in Chl- $a$ concentrations and Chl- $a$ /(Chl- $a+$ Phaeo- $a$ ) ratios. Overall, the coordinates of stations on the first axis of the PCA correlated significantly with station depth at the scale of both the whole WGMP and its sole distal part $\left(n=31, \mathrm{R}^{2}=0.561, p<0.001 ; n=24, \mathrm{R}^{2}=0.366, p=0.002\right)$. 

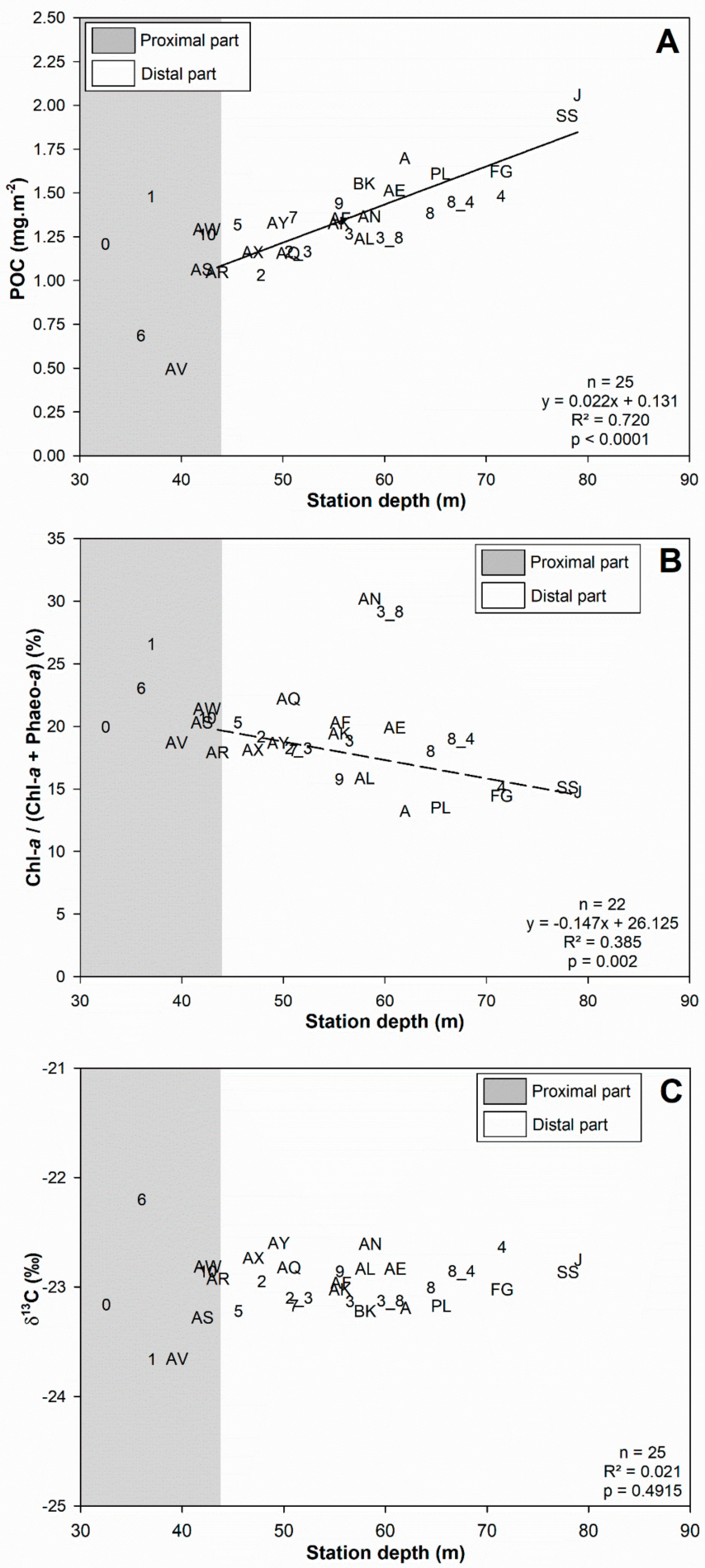

Figure 3. Relationships between station depth and main surface sediment characteristics: Particulate Organic Carbon concentration (POC; (A)); Chl- $a /(\mathrm{Chl}-a+\mathrm{Phaeo}-a)$ ratio $(\mathbf{B})$ and $\delta^{13} \mathrm{C}(\mathbf{C})$. Gray areas represent the proximal part $(\mathrm{z}<42.5 \mathrm{~m})$ of the WGMP. Station codes are the same as in Figure 1 and Table A1. The continuous line represents the linear regression linking station depth and POC concentration within the distal part of the WGMP, and the dotted line represents the linear regression linking station depth and Chl- $a$ / (Chl- $a+$ Phaeo- $a$ ) ratio within the distal part of the WGMP (excluding stations AN and 3_8). 


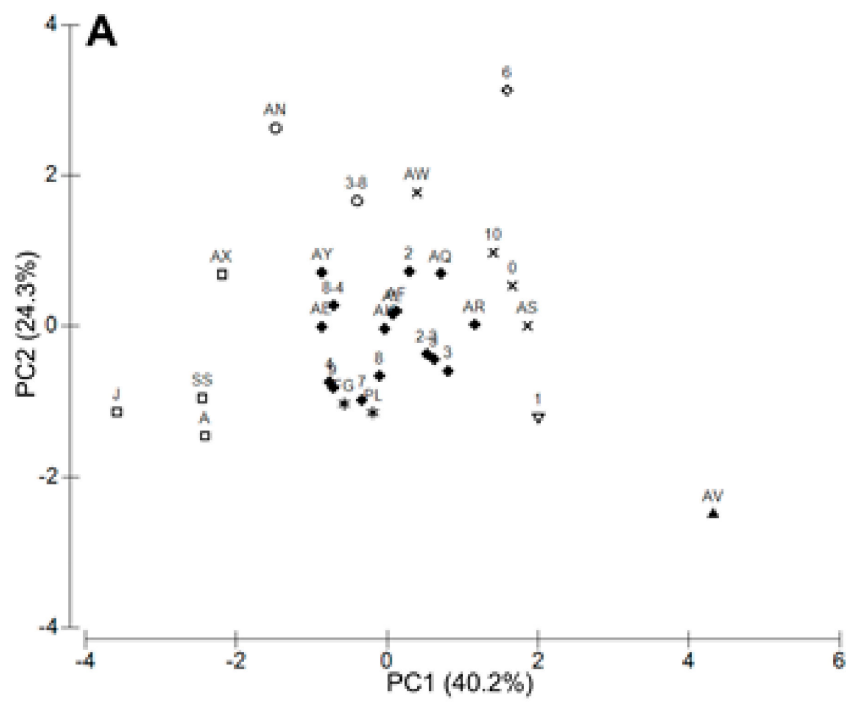

B
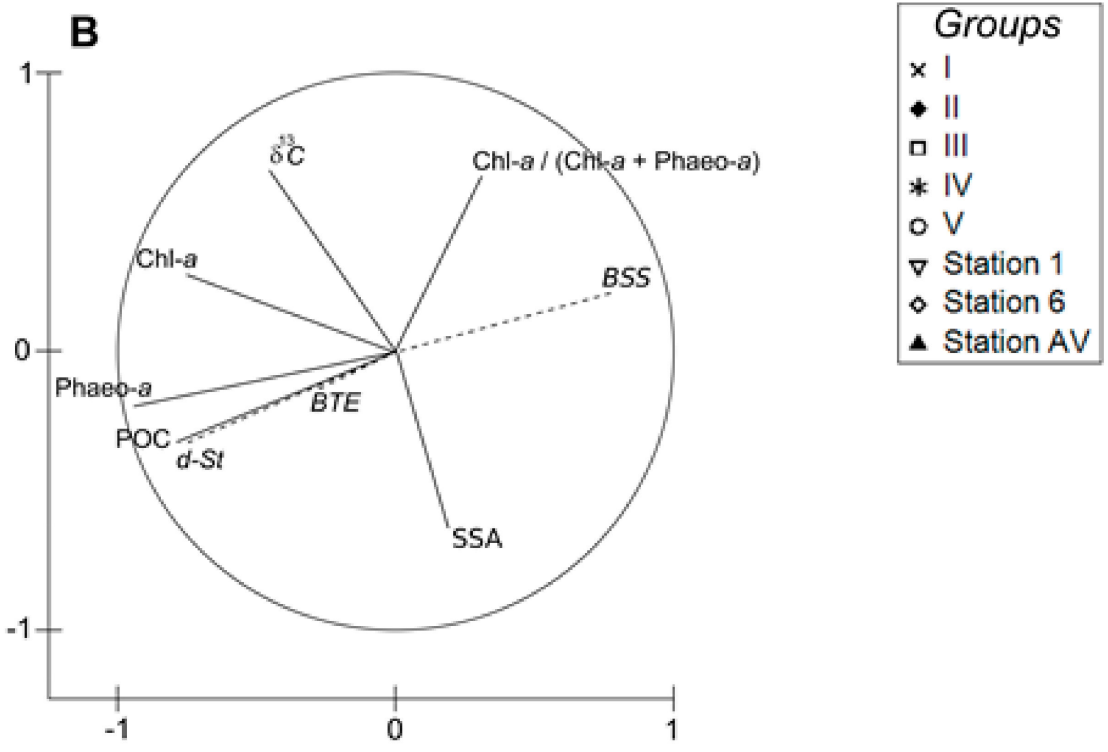

Figure 4. Principal component analysis based on normalized surface sediment characteristics (Sediment Surface Area (SSA), POC, Chl- $a$, Phaeo- $a$, Chl- $a /(\mathrm{Chl}-a+\mathrm{Phaeo}-a)$ ratio and $\left.\delta^{13} \mathrm{C}\right)$. Projection of stations on the first plane of the Principal Components Analysis (PCA) (A) and correlations of the variables with the first two components (B). Station depth (d-St), Bottom Shear Stress (BSS) and Bottom Trawling Effort (BTE) were used as supplementary variables. Group identification was achieved through the coupling of hierarchical clustering with a SIMilarity PROFile (SIMPROF) procedure. Station codes are the same as in Figure 1 and Table A1.

\subsection{X-rays Radiographies}

Examples of X-rays radiographies are shown in Figure 5. Stations 0 and 10 showed the presence of a ca. 6-7 cm thick surface sandy layer. Station 10 also presented traces of biological mixing within this layer. Both stations showed laminae corresponding to the denser particles deposits in the sediment column $(\mathrm{z} \approx 13 ; 16 ; 17 ; 19 \mathrm{~cm}$ at station 0 and $\mathrm{z} \approx 8 \mathrm{~cm}$ at station 10 ). These structures were less numerous at deeper stations. Nevertheless, some larger structures were observable: (1) at station 2-3 where a coarse layer $(\mathrm{z} \approx 14 / 15 \mathrm{~cm})$ was overlaid by a finer one $(11<\mathrm{z}<14 \mathrm{~cm})$, and $(2)$ at station 4 where two denser (centimeter scaled) layers surrounded a finer one $(10<\mathrm{z}<14.5 \mathrm{~cm})$. Overall, $\mathrm{X}$-rays radiographies clearly showed an increase in the thickness of the bioturbated layer 
between stations 10 and J, whereas station 0 presented only superficial biological reworking within the surface sandy layer.
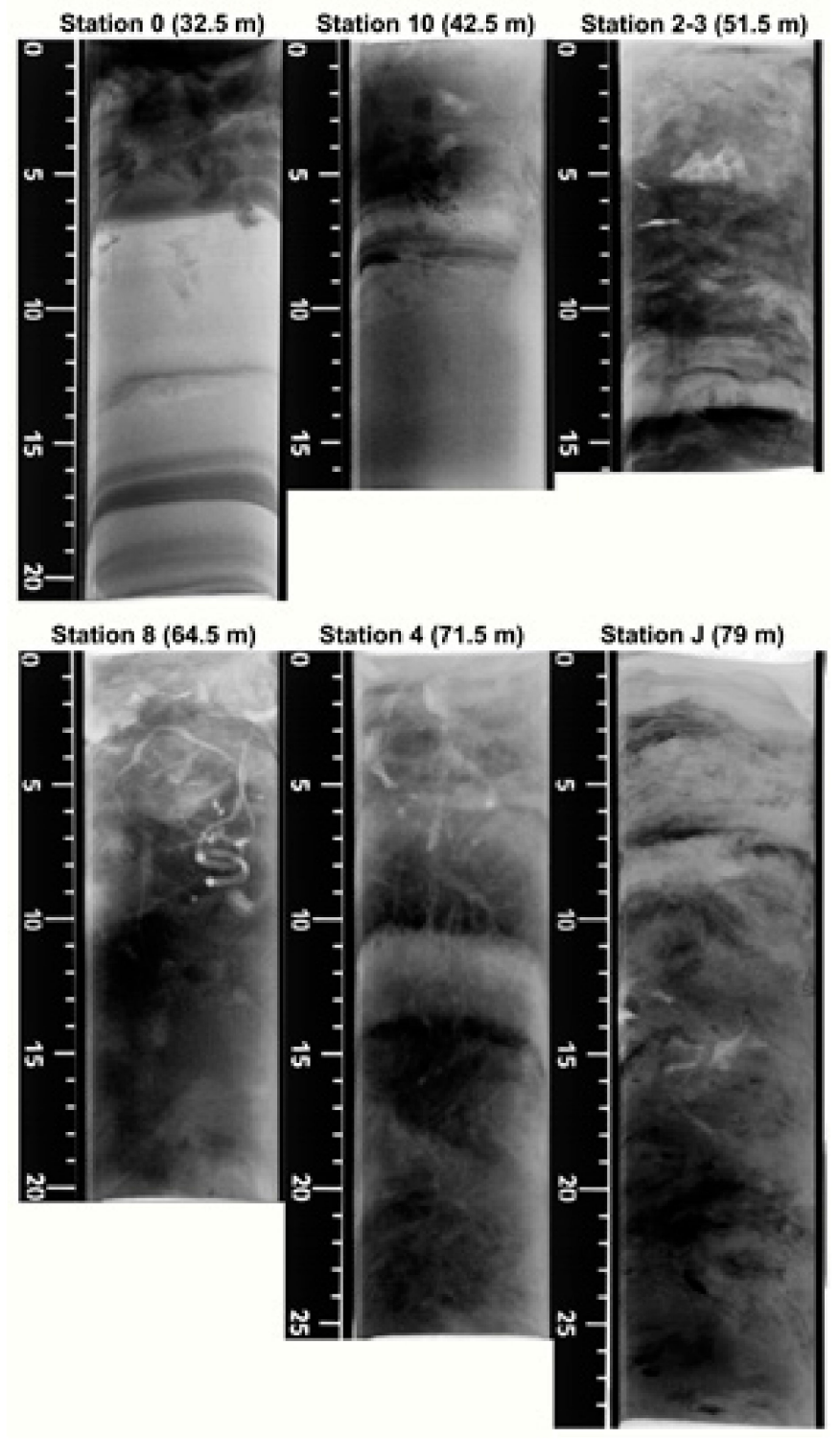

Figure 5. Examples of X-rays radiographies (positives; scale in $\mathrm{cm}$ ) collected at six stations located along the sampled depth gradient (see Figure 1). Station codes are the same as in Figure 1 and Table A1.

\subsection{Sediment Profile Images}

Overall, 186 Sediment Profiles Images (SPI) were captured. Representative examples (Figure 6) show the increases in the mean values of: (1) aRPD thickness, (2) total number of biological traces (i.e., biogenic structures + epi + infauna), and (3) the thickness of the sediment layer containing biogenic structures with station depth. They also clearly show the presence of a top coarser sediment layer covering dark mud at station 0 . 


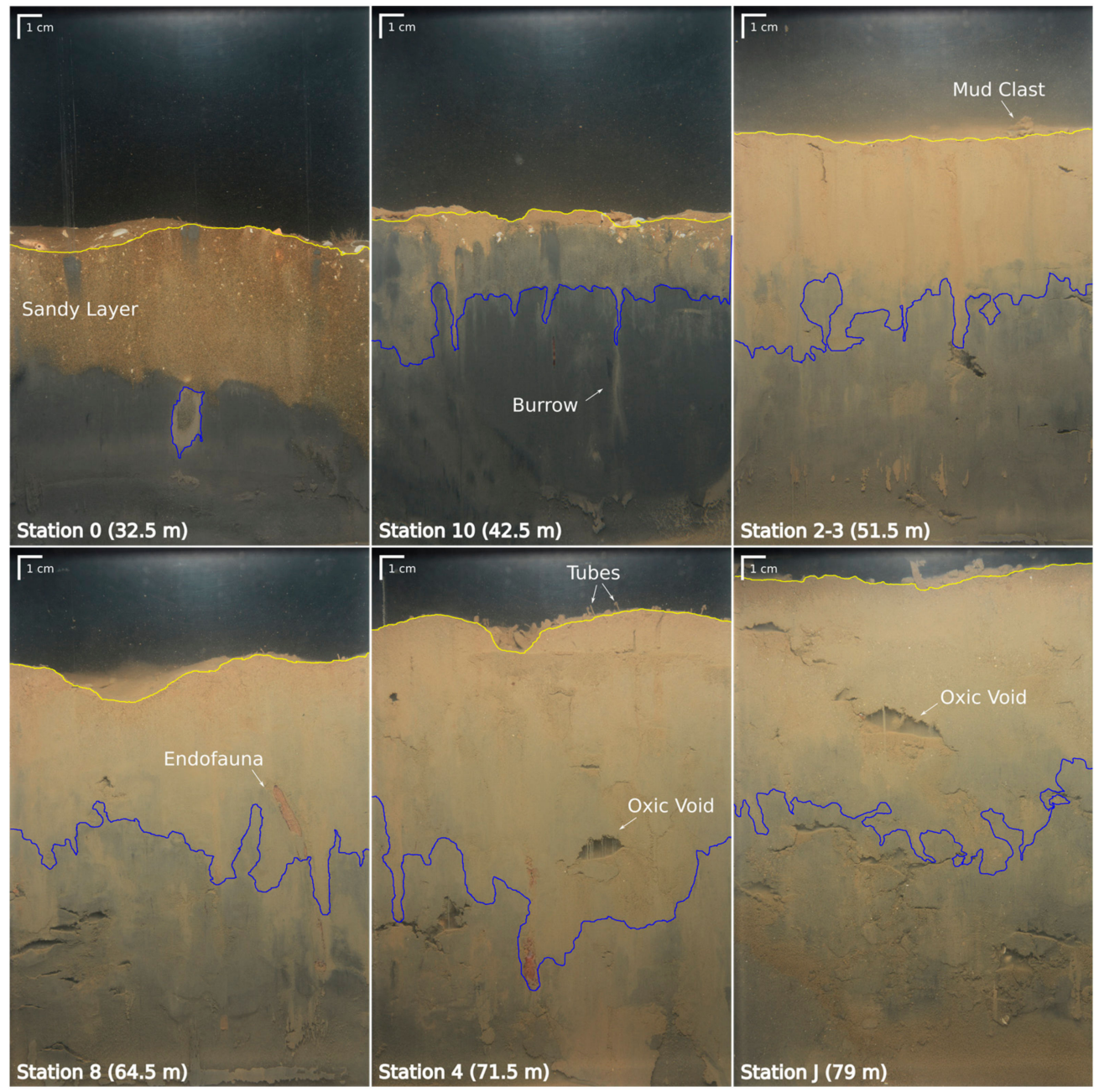

Figure 6. Examples of Sediment Profile Images (SPI) collected at six stations located along the depth gradient sampled for X-rays radiographies (see Figure 1). Yellow lines represent sedimentwater interfaces and blue lines represent apparent Redox Potential Discontinuity (aRPD) thicknesses. Stations are the same as in Figure 5, and codes are the same as in Figure 1 and Table A1.

At the scale of the whole WGMP, all SPI characteristics correlated significantly with station depth except for the number of infauna (Table A2). All significant correlations were positive except for number of epifauna. Examples of such relationships are given in Figure 7 for mean (1) aRPD thickness, (2) total number of biological traces (i.e., biogenic structures + epi- and infauna), and (3) maximal depth of oxic voids. These three parameters presented low values and, for some of them (i.e., aRPD thickness and maximum depth of oxic void), there was a high between-station variability in the proximal part. Within the distal part, they correlated significantly with station depth (Table A2), which was also the case of most other SPI characteristics (i.e., except for burrow and infauna numbers). All significant correlations were positive except for the number of epifauna. For both the whole WGMP and its sole distal part, the proportions of explained variance remained low (Table A2). They were higher for aRPD thickness, oxic void number and maximal depth, and tube number. This proportion was higher for the total number of biological traces than for any individual SPI characteristic. 

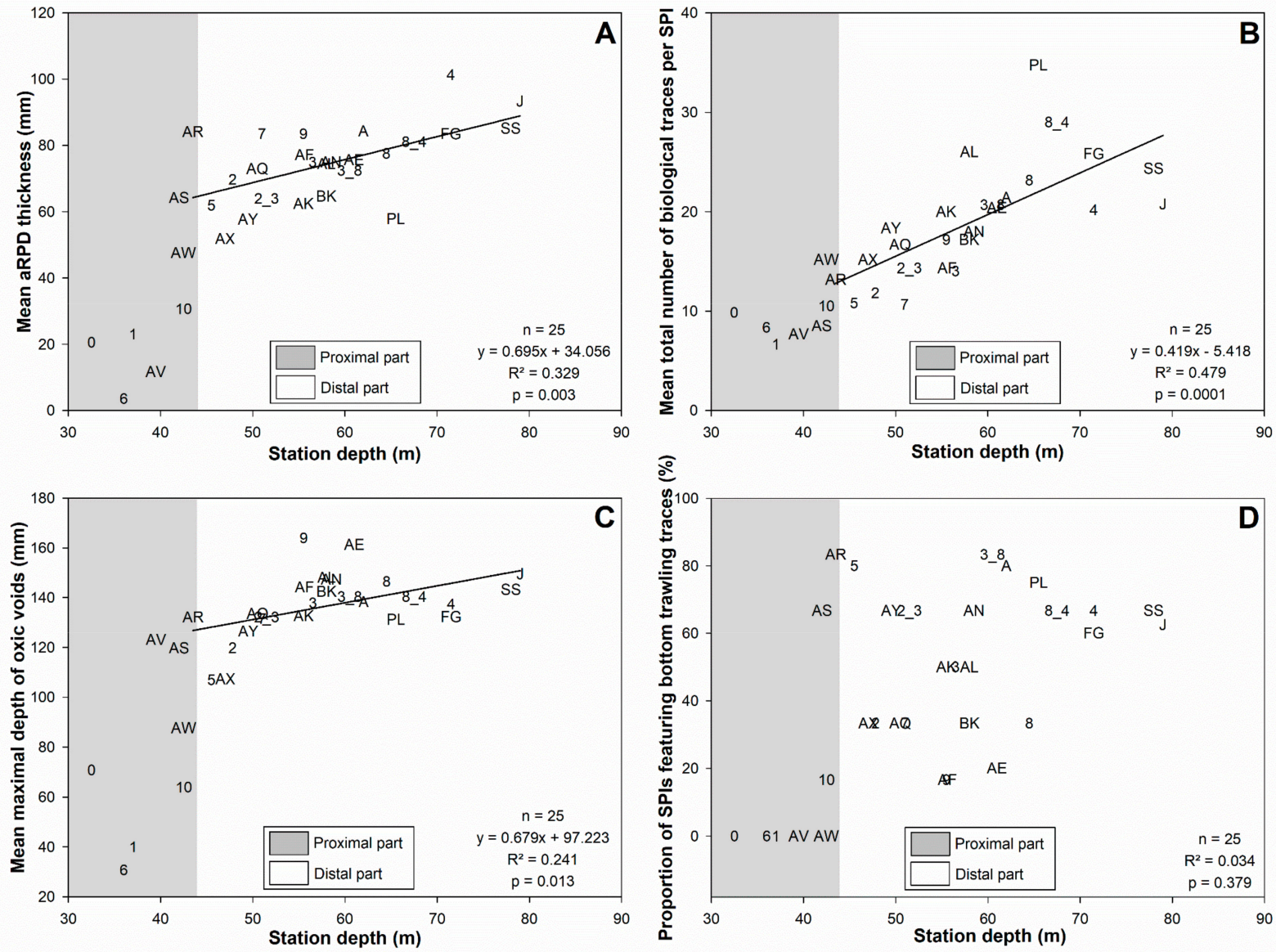

Figure 7. Relationships between station depth and mean main SPI characteristics: aRPD thickness (A), total number of biological traces per SPI (B), maximal depth of oxic voids (C), and proportion of SPIs featuring bottom trawling traces (D). Gray areas represent the proximal part $(\mathrm{z}<42.5 \mathrm{~m})$ of the WGMP. Station codes are the same as in Figure 1 and Table A1. Continuous lines represent the linear regressions linking station depth and mean SPI characteristics within the distal part of the WGMP.

The first two components of the PCA based on SPI characteristics explained 58.2\% (i.e., $42.5 \%$ and $15.7 \%$ for the first and the second principal component, respectively) of the total variance (Figure 8A). The first component was mainly characterized by a set of co-correlated subsurface features (i.e., number and maximal depth of oxic voids, number of burrows and aRPD thickness). The second component was mostly driven by the number of feeding pits (Figure 8B). Hierarchical clustering and the associated SIMPROF procedure resulted in the identification of three groups of stations (Figure 8A), one of them including only a single station. Group I was composed of five of the seven shallowest stations (i.e., stations $0,1,6,10$, and $\mathrm{AV}$ ), and group II was composed of all other stations except station AY due to a high number of epifauna. The SPI characteristics accounting most for differences between groups I and II were (1) aRPD thickness (22.3\%), (2) oxic void maximal depth (22.0\%), (3) burrow number (14.4\%), and (4) oxic void number $(13.5 \%)$. The coordinates of stations on the first axis of the PCA correlated significantly with station depth at the scale of both the whole WGMP and its sole distal part $\left(n=32, \mathrm{R}^{2}=0.757\right.$, $p<0.001 ; n=25, \mathrm{R}^{2}=0.601, p<0.001$; respectively). 


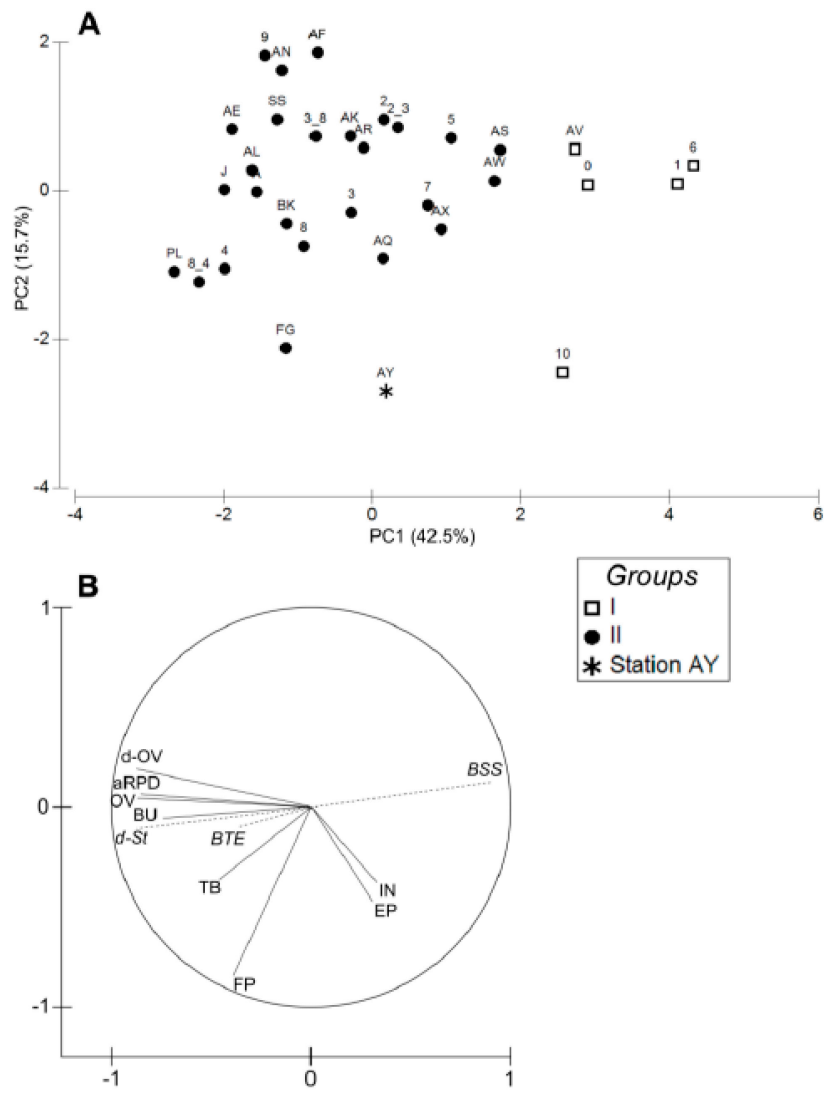

Figure 8. Principal component analysis based on normalized mean SPI characteristics (aRPD: aRPD thickness; BU: number of burrows; OV and d-OV: number and maximal depth of oxic voids; FP: number of feeding pits; TB: tubes; EP: epifauna and IN: infauna). Projection of stations on the first plane of the PCA (A), and correlations of the variables with its first two components (B). Station depth (d-St), Bottom Shear Stress (BSS), and Bottom Trawling Effort (BTE) were used as supplementary variables. Group identification was achieved through the coupling of hierarchical clustering with a SIMPROF procedure. Station codes are the same as in Figure 1 and Table A1.

Mud clasts were observed in 80 out of 186 SPIs, whereas furrows were recorded on only two images and surface puzzle fabrics were never observed. SPIs from five of the shallowest stations did not show any of these traces at all (Figure 7D). There was otherwise high among-station variability in the proportion of SPI containing such features. The proportion of SPI featuring traces indicative of bottom trawling correlated significantly with station depth at the scale of the whole WGMP, but this correlation was not significant within the sole distal part (Table A2).

\subsection{Bottom Shear Stress and Bottom Trawling Effort}

BSS 95th percentiles significantly decreased with station depth at the scale of the whole WGMP and of its sole distal part (Figure 9A,B and Table A2). Their values within cells containing sampled stations were between 0.42 at station $\mathrm{J}$ and $1.10 \mathrm{~N} \cdot \mathrm{m}^{-2}$ at station 0 (Figure 9B and Table A1). In the distal part, POC, Phaeo- $a$, and THAA correlated negatively with BSS 95th percentiles. This was also the case for six (i.e., aRPD thickness; numbers of oxic voids, feeding pits, tubes; maximal depth of oxic voids; and total number of biological traces; Table A3) of the 10 SPI characteristics assessed during the present study. Moreover, at the scale of the sole WGMP distal part, the coordinates of stations on the first axis of the PCAs based on both surface sediment and SPI characteristics correlated significantly with BSS ( $n=24, \mathrm{R}^{2}=0.348, p=0.002 ;$ and $n=25, \mathrm{R}^{2}=0.547, p<0.001$; respectively). 

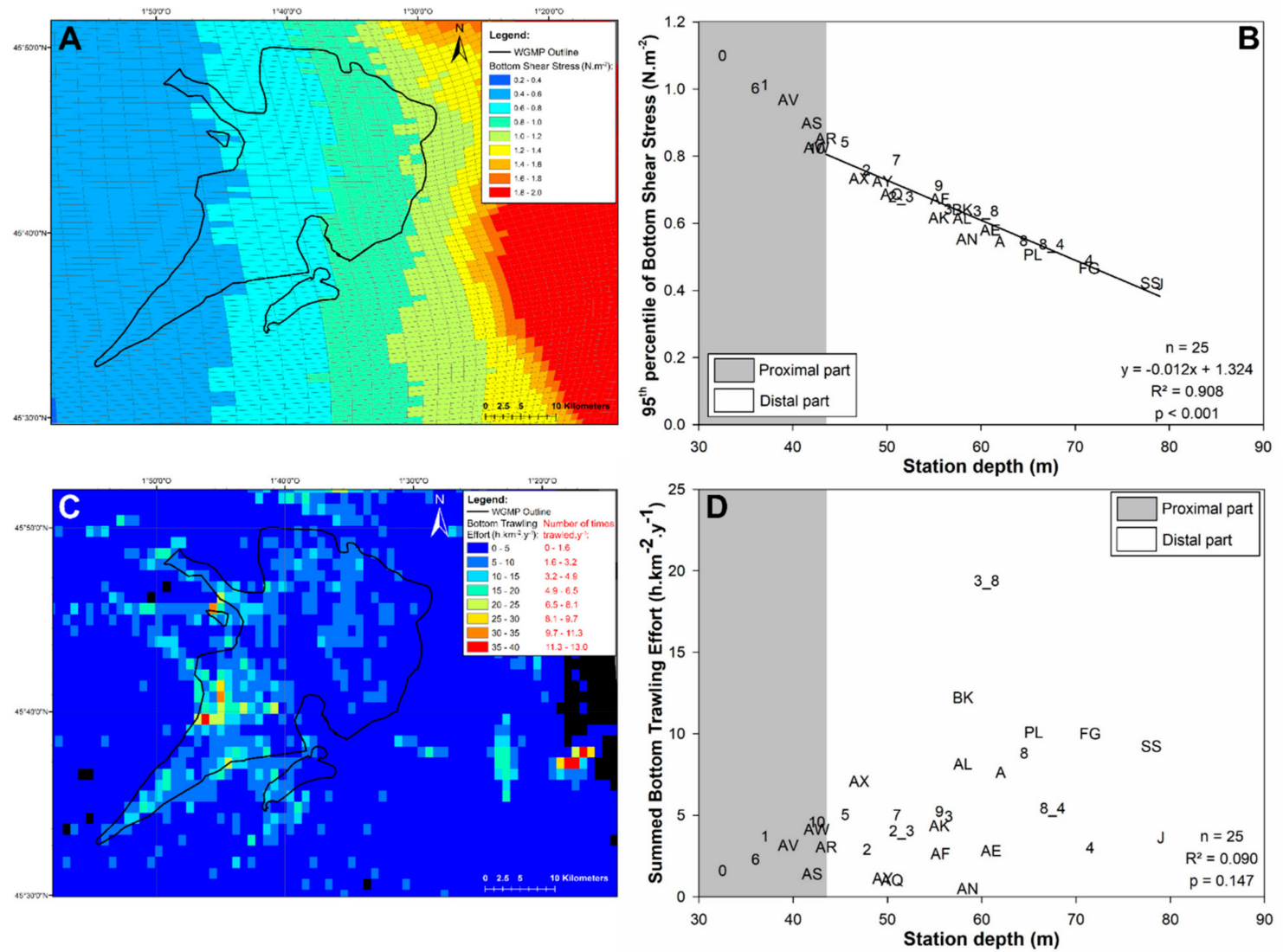

Figure 9. Spatial mapping of 95th percentile of Bottom Shear Stress during the year preceding the JERICOBENT-5 cruise (A), relationship with station depth within cells including sampled stations (B), summed Bottom Trawling Effort during the year preceding the JERICOBENT-5 cruise (C), and relationship with station depth within cells including sampled stations (D). Gray areas represent the proximal part $(\mathrm{z}<42.5 \mathrm{~m})$ of the WGMP. Station codes are the same as in Figure 1 and Table A1.

Bottom Trawling Effort (BTE) tended to be higher in the WGMP than in adjacent areas (Figure 9C). It was low in the shallowest part (i.e., $35<\mathrm{z}<50 \mathrm{~m}$ ) of the WGMP. Deeper, BTE was highly heterogeneous with some cells being heavily trawled between 55 and $60 \mathrm{~m}$ depth (i.e., up to $39.6 \mathrm{~h} \cdot \mathrm{km}^{-2} \cdot \mathrm{y}^{-1}$ and 12.9 times trawled $\cdot \mathrm{y}^{-1}$; Figure $9 \mathrm{C}$ ), while some others were only lightly affected. BTE within cells containing sampled stations was between 0.48 and $19.4 \mathrm{~h} \cdot \mathrm{km}^{-2} \cdot \mathrm{y}^{-1}\left(0.2\right.$ and 6.3 times trawled $\cdot \mathrm{y}^{-1}$ for stations AN and 3-8, respectively; Figure 9D and Table A1). Four sampled stations (3-8, BK, PL, and FG) were located in cells featuring a BTE higher than $10 \mathrm{~h} \cdot \mathrm{km}^{-2} \cdot \mathrm{y}^{-1}$ (Figure 9D and Table A1). BTE within cells containing sampled stations correlated positively with station depth at the scale of the whole WGMP, but this correlation was not significant in the sole distal part (Table A2). In the distal part, there was no significant correlation between BTE and any surface sediment or SPI individual characteristic (including the proportion of SPI featuring traces indicative of bottom trawling), except for (1) $\delta^{13} \mathrm{C}$, (2) Chl- $a /(\mathrm{Chl}-a+$ Phaeo- $a$ ), and (3) numbers of tube and total biological traces (which was largely affected by tube number; Table A3). Moreover, at the scale of the sole WGMP distal part, the coordinates of stations on the first axis of the PCAs based on both surface sediment and SPI characteristics did not correlate significantly with BTE $\left(n=24, \mathrm{R}^{2}=0.003, p=0.813\right.$; and $n=25, \mathrm{R}^{2}=0.038$, $p=0.347$; respectively).

\subsection{Comparison with the Rhône River Prodelta}

The relationships between station depth and $\mathrm{D}_{0.5}$, THAA, Chl- $a$ /(Chl- $a+$ Phaeo- $\left.a\right)$, and $\delta^{13} \mathrm{C}$ in both the distal part of the WGMP and the Rhône River Prodelta (RRP) show clear differences between the two systems (Figure 10). With the exception of the RRP 
shallowest station, surface sediments were significantly $(p<0.001)$ coarser in the distal part of the WGMP (mean $\mathrm{D}_{0.5}$ of $20.2 \mu \mathrm{m}$ ) than in the RRP (i.e., mean $\mathrm{D}_{0.5}$ of $12.0 \mu \mathrm{m}$; Figure 10A). Mean THAA concentrations were significantly higher in the distal part of the WGMP than in the RRP (mean values and standard deviations of $4.20 \pm 1.23 \mathrm{mg} \cdot \mathrm{gDW}^{-1}$ and $2.75 \pm 0.55 \mathrm{mg} \cdot \mathrm{gDW}^{-1}$, respectively; $p=0.013$ ). Moreover, changes in THAA concentrations relative to station depth showed opposite patterns in the two systems with increasing values with increasing depth in the distal part of the WGMP and decreasing values with increasing depth in the RRP (Figure 10B). The same result was found after standardization for $\mathrm{D}_{0.5}$. Similar discrepancies between systems were found for POC and EHAA concentrations even though mean POC concentrations were significantly lower in the distal part of the WGMP $(1.09 \pm 0.24$ vs. $1.39 \pm 0.29 \% \mathrm{DW}$ in the RRP; $p=0.021)$, and mean EHAA concentrations did not significantly differ between systems $(0.76 \pm 0.13$ vs. $0.77 \pm 0.19 \mathrm{mg} \cdot \mathrm{gDW}^{-1}$, in the distal part of the WGMP and the RRP, respectively; $p=0.846)$. Chl- $a /($ Chl- $a+$ Phaeo- $a)$ ratio significantly decreased with increasing station depth in both systems (Figure 10C) with no significant difference in their mean values $(p=0.105)$. EHAA/THAA ratios did not correlate significantly with station depth in either system ( $p=0.202$ and $p=0.950$ in the distal part of the WGMP and the RRP, respectively). Their mean value was significantly lower in the distal part of the WGMP than in the RRP $(19.8 \pm 3.4 \%$ and $27.7 \pm 1.5 \%$, respectively; $p<0.001)$. The pattern of changes in $\delta^{13} \mathrm{C}$ relative to station depth clearly differed between systems with significantly increasing values with increasing station depth in the RRP $(p=0.005)$ and no significant change in the distal part of the WGMP. Their mean value was significantly $(p<0.001)$ less negative in the WGMP $(-22.9 \%)$ than in the RRP $(-25.7 \%)$.
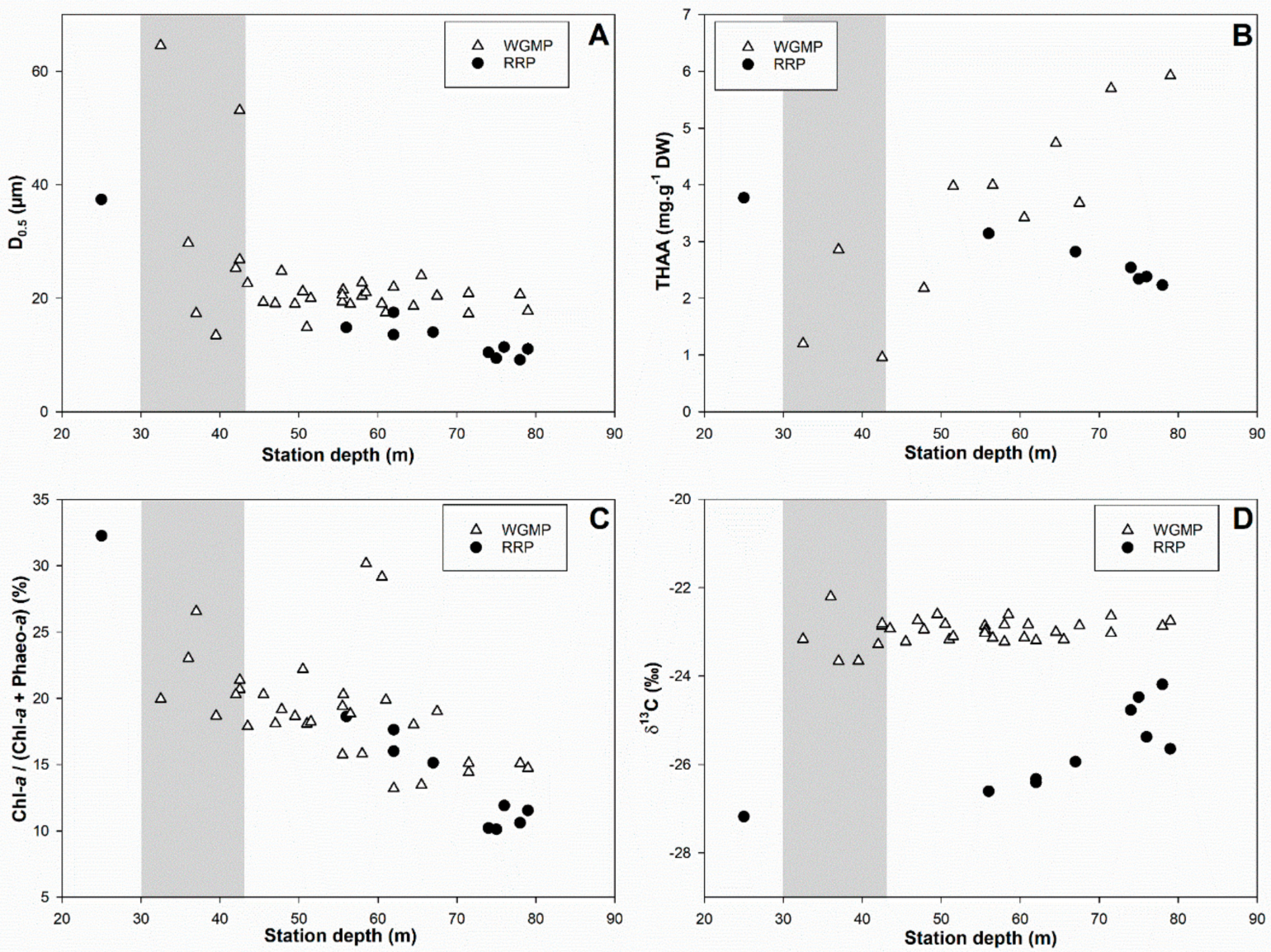

Figure 10. Relationships between station depth and main surface sediment characteristics in the WGMP and the Rhône River Prodelta (RRP): $\mathrm{D}_{0.5}$ (A), Total Hydrolyzable Amino Acids (THAA (B)), Chl- $a /\left(\right.$ Chl- $a+$ Phaeo- $a$ ) ratio $\left(\right.$ C), and $\delta^{13} \mathrm{C}$ (D). Gray areas represent the proximal part of the WGMP $(\mathrm{z}<42.5 \mathrm{~m})$. 
The relationships between station depth and (1) aRPD thickness, (2) total number of biological traces per SPI, and (3) depth of oxic voids in both the distal part of the WGMP and the RRP are shown in Figure 11. The two systems presented strong differences. aRPD thickness increased with station depth in both the distal part of the WGMP and in the RRP $(p=0.003$ and $p=0.002$, respectively; Figure 11A), but its mean was significantly higher in the distal part of the WGMP $(74.8 \pm 11.7$ vs. $37.0 \pm 18.1 \mathrm{~mm}$ in the RRP; $p<0.001)$. The mean total number of biological traces was also significantly higher in the distal part of the WGMP (Figure 11B; $19.1 \pm 5.9$ vs. $4.7 \pm 2.2$ per SPI in the RRP; $p<0.001$ ). There were similar differences for the mean numbers of burrows, oxic voids, and tubes $(p<0.001$ in all cases). Mean oxic void depth significantly increased with station depth in the RRP $(p=0.022)$ but not in the distal part of the WGMP $(p=0.745)$. Its mean value was also significantly higher, although to a lower extent, in the distal part of the WGMP (Figure 11C; $86.7 \pm 15.0$ vs. $68.5 \pm 29.4 \mathrm{~mm}$, in the RRP; $p=0.023$ ).
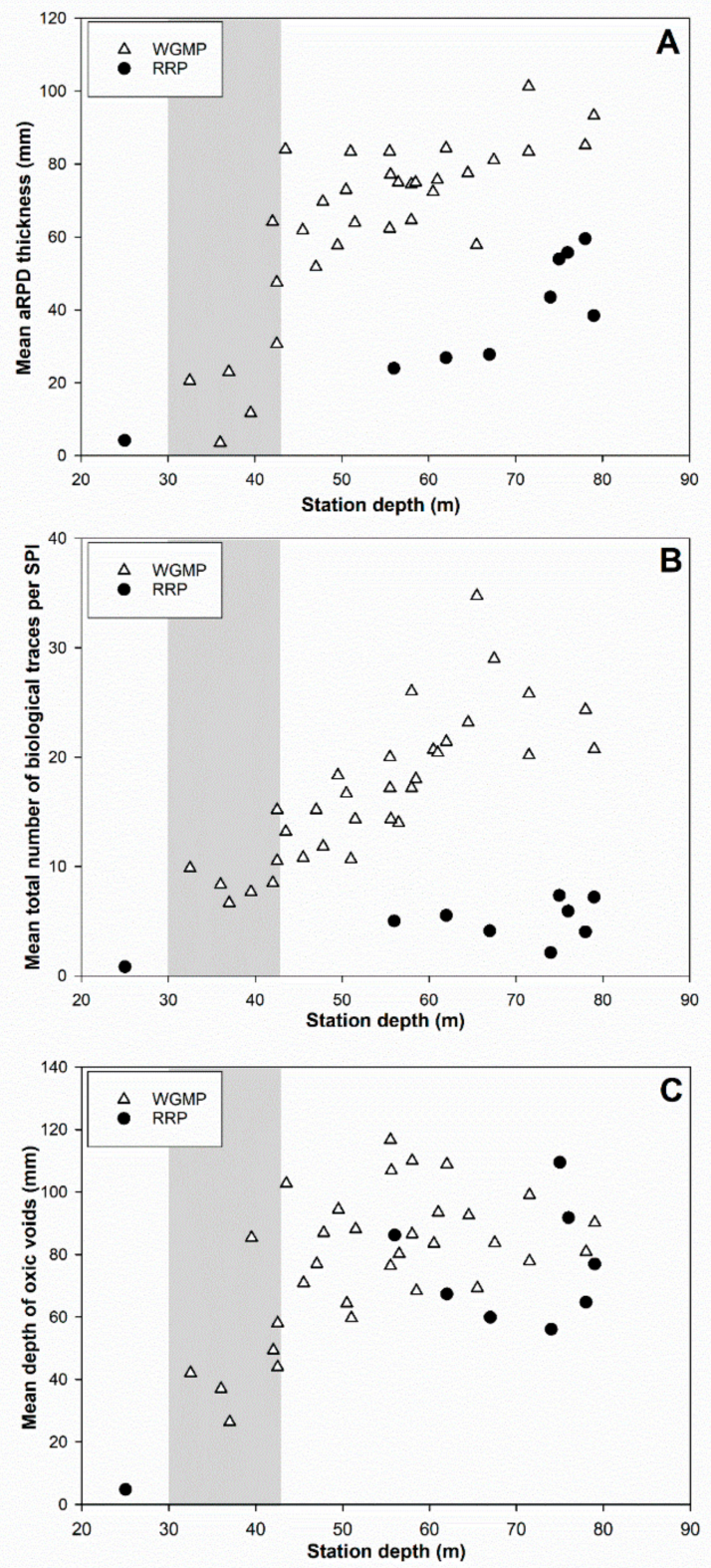

Figure 11. Relationships between station depth and mean main SPI characteristics in the WGMP and the RRP: aRPD thickness (A), total number of biological traces per SPI (B), and depth of oxic voids (C). Grey areas represent the proximal part of the WGMP $(\mathrm{z}<42.5 \mathrm{~m})$. 


\section{Discussion}

\subsection{Spatial Structuration}

\subsubsection{Subdivision between Proximal and Distal Parts}

Up to now, only two studies have considered the spatial distribution of surface sediment grain size and organic contents in the West Gironde Mud Patch (WGMP; [44,45]). Both studies relied on the sampling of only three stations, and their results supported the original $[26,34,40]$ distinction between a proximal and a distal part. Our sampling plan was based on 32 stations, which allowed showing a significant correlation between surface sediment characteristics (as summarized by the first component of the corresponding PCA) and station depth. Data analysis resulted in the identification of three main groups of stations presenting different surface sediment characteristics. Stations of groups I (together with stations 1,6 , and $\mathrm{AV}$ ) were all shallow $(\mathrm{z}<42.5 \mathrm{~m})$ and tended to present coarse surface sediments and low concentrations in Particular Organic Carbon (POC) and chloropigments. A high between-station variability in $\mathrm{D}_{0.5}$ and Sediment Surface Area (SSA) was nevertheless recorded in this group, most likely reflecting spatial differences in the transient deposition of coarse sediments $[25,26,40]$ as observed during the present study on the Sediment Profile Images (SPIs) collected at station 0 . Therefore, our results clearly support that the stations of group I, and associated isolated stations are constitutive of the proximal part of the WGMP as stated by Jouanneau et al. [35] and Lesueur et al. [26,34].

The spatial zonation of the WGMP has also been studied based on X-rays radiographies of long sediment cores [26,34,35,40,43]. Lesueur and Tastet [43] computed a crude index of bioturbation (i.e., the proportion of reworked sediment volume) based on these radiographies. They proposed to subdivide the WGMP in three parts based on the values of this index, which increased with station depth. The shallowest part could be considered as mostly representative of the proximal and the two others of the distal part (Lesueur and Tastet [43]). However, this conclusion clearly suffered from (1) the inability of X-rays radiographies to precisely assess bioturbation and (2) the use of long sediment cores, which did not allow for the preservation of the sediment-water interface. The $\mathrm{X}$-rays radiographies collected during the present study were achieved on cores collected using a lightweight interface corer, which allowed for a better preservation of this interface. Results confirmed previous observations in showing (1) the occurrence of sandy layers in the top sediment column of the three stations sampled within the proximal part (see above); (2) the presence, especially at shallow stations, of laminae attributed by Lesueur and Tastet [43] to the deposition of dense and coarse particles following high energy events; and (3) a limitation of bioturbation to the top of the sediment column at shallow stations, whereas the thickness of the mixed sediment layer was clearly higher at deep stations. During the present study, we also used Sediment Profile Imagery, which allowed for (1) an in situ 2D visualization of the sedimentary column without disturbing the sediment-water interface and (2) a multiparametric assessment of modern bioturbation through the analysis of biological traces [63]. This resulted in the identification of two main groups of stations delimited by a ca. $42.5 \mathrm{~m}$ depth threshold, which further supports the distinction between a proximal part where bioturbation is limited and a distal part where it is much higher (Figure 7A-C).

\subsubsection{Spatial Structuration of the Distal Part}

Previous sedimentological surveys have shown the occurrence of two major depth gradients in the distal part $[26,34,35,40,43]$. The first related to the frequency of occurrence of erosional surfaces and subsequent vertical decreasing granulometric sequences (see above), and the second related to bioturbation. However, these surveys did not account for modern biogeochemical processes taking place in the top of the sediment column. This issue was tackled by Relexans et al. [44] and later by Massé et al. [45] based on the analyses of surface sedimentary organics and benthic fauna composition. However, results remained largely inconclusive regarding the possible existence of spatial gradients due to limited sampling efforts. 
During the present study, we sampled 25 stations within the distal part. Based on the multivariate analysis of their surface sediment characteristics, these stations were mostly distributed among two main groups, which were clearly related to station depth as confirmed by the significance of the correlations linking station depth with (1) POC, THAA, and Phaeo- $a$ concentrations and (2) the coordinates of stations on the first component of the PCA based on surface sediment characteristics within the distal part of the WGMP. A significant correlation was also found for the Chl- $a$ /(Chl- $a+$ Phaeo- $a$ ) ratio when excluding two outliers. Thus, our results clearly support the occurrence of a depth gradient in surface sediment characteristics within the distal part of the WGMP. This gradient was linked to changes in sedimentary organic characteristics and independent of changes in sediment granulometry, since all organic concentrations were normalized to SSA.

The two statistical approaches used to assess the existence of a potential depth gradient based on SPI characteristics led to apparently different conclusions. On the one hand, regression analyses showed significant correlations between most individual characteristics and station depth, and there was a significant correlation between station depth and station coordinates on the first component of the PCA based on SPI characteristics. On the other hand, the hierarchical clustering based on the whole set of SPI characteristics together with the associated SIMPROF procedure failed to identify significantly differing station subgroups. Most of the assessed individual SPI characteristics correlated significantly with station depth, and for five of them, this was indicative of an increase in bioturbation with station depth. This trend was particularly marked for (1) sediment oxidation (aRPD), (2) burrowing (oxic void number), and (3) thickness of the mixed sediment layer (oxic void maximal depth). Conversely, neither infauna nor burrow numbers did significantly correlate with station depth. For infauna, this may result from undersampling. For burrow number, this probably results from (1) large spatial extensions at highly bioturbated deep stations, which complicates the distinction between burrows and may induce an underestimation of their number; and (2) stronger difficulties in identifying burrows (i.e., oxidized structures) within sediment columns featuring thicker aRPDs at deep stations. Interestingly, the positive correlation with station depth was more pronounced for the total number of biological traces (although this last parameter included the epifauna number, which correlated negatively with station depth) than for any SPI individual characteristic. This can be interpreted as a reduction (by summation) of the lack of fit of the regression models linking station depth and individual SPI characteristics, which further supports the existence of a gradient of increasing bioturbation along the depth gradient within the distal part of the WGMP. The fact that hierarchical clustering based on SPI characteristics did not allow differentiating station subgroups is likely caused by (1) the use of normalized data, which resulted in the attribution of the same weight to all considered parameters, including those that did not correlate significantly with station depth (i.e., burrow and infauna numbers); and (2) the noise generated by the lack of fit of the regression models linking station depth and individual SPI characteristics, which differed between characteristics for a given station (as exemplified above for the total number of biological traces). Therefore, our interpretation of SPI data is that they also support the existence of a depth gradient of increasing bioturbation within the distal part.

\subsubsection{Overall Conclusion}

Based on a wide range of surface sediment characteristics and the use of an image analysis technique specifically designed for the top of the sediment column, our results clearly confirm the subdivision of the WGMP in a proximal and a distal part put forward by previous sedimentological surveys and support the proposed $40-45 \mathrm{~m}$ depth limit between these two parts $[26,43]$. They also show the existence of a depth gradient resulting from modern sedimentation and bioturbation processes taking place in the distal part of the WGMP. 


\subsection{Disentangling the Potential Effects of Hydrodynamics and Bottom Trawling}

The potential impacts of hydrodynamics and bottom trawling on the spatial distributions of surface sediment and SPI characteristics were tested by the simultaneous assessments of the spatial distributions of (1) Bottom Shear Stress (BSS), (2) Bottom Trawling Effort (BTE), (3) surface sediment characteristics, and (4) SPI features. When considering the whole WGMP, the correlations between both BSS and BTE with station depth impaired the unraveling of the role of these two factors in controlling the spatial distribution of surface sediment and SPI characteristics. More generally, the correlation between environmental characteristics and fishing effort clearly constitutes a major issue when assessing the impact of benthic trawling on benthic systems $[23,83,84]$. During the present study, this difficulty was overcome by considering spatial changes recorded in the sole distal part where (1) BTE did not correlate significantly with station depth, (2) the ranges of $\mathrm{D}_{0.5}$ and SSA were narrower, and (3) none of these two parameters correlated significantly with both BSS and BTE (see Queirós et al. [24] for a similar approach).

The 95th BSS percentiles recorded during the present studies were between 0.4 and $1.1 \mathrm{~N} \cdot \mathrm{m}^{-2}$. These values can be compared with those computed in the Gulf of Lions using a similar model (i.e., a 90th percentile around $0.05 \mathrm{~N} \cdot \mathrm{m}^{-2}$ at a $30 \mathrm{~m}$ depth; [85]). Moreover, based on simultaneous assessments of BSS and Suspended Particulate Matter concentration, Dufois et al. [78] concluded that resuspension was induced over a critical BSS threshold of $0.35 \mathrm{~N} \cdot \mathrm{m}^{-2}$ at a $20 \mathrm{~m}$ deep station within the Rhône River Prodelta. Although caution should clearly be taken since sediment roughness and rheological properties were not assessed during the present study, this supports the hypothesis according to which sediment resuspension may take place over the whole WGMP [47]. Moreover, the 95th percentile value of BSS correlated negatively with station depth, which largely corresponded to the dominance of its wave-induced component relative to its currentinduced component and is also coherent with the dominant role attributed to waves in controlling the spatial structuration of the WGMP [26]. Although collected over different periods (June 2017-June 2018 vs. 2005-2013) and using different positioning systems (i.e., Automatic Identification System vs. Vessel Monitoring System), the absolute values and the spatial distribution of BTE observed during the present study were fully consistent with the one reported by Mengual et al. $[19,20]$. BTE was clearly higher within the distal part with a maximal average number of times trawled $\cdot \mathrm{y}^{-1}$ of 12.9 .

Several lines of evidence suggest that the effect of bottom trawling on the spatial distributions of both surface sediment and SPI characteristics was limited as compared to the influence of hydrodynamics. First, there were significant correlations between three (four when excluding the two above-mentioned outliers for Chl- $a$ / (Chl- $a+$ Phaeoa)) of surface sediment characteristics and BSS, whereas only $\delta^{13} \mathrm{C}$ (although featuring a very restricted range of variation) and Chl- $a /(\mathrm{Chl}-a+$ Phaeo- $a$ ) (when excluding the two above-mentioned outliers) correlated significantly with BTE. Second, most of the SPI individual characteristics correlated negatively with BSS, whereas the number of tubes was the only individual SPI characteristic significantly correlating with BTE. Furthermore, this last result is not supporting a strong effect of bottom trawling, since BTE is generally assumed to negatively impact benthic bioturbation [24,83,84,86-89]. Along the same line, the correlation between tube number and BTE was positive, which here again is not supporting a strong influence of bottom trawling, since according to the literature, tube-building species tend to be rare or even absent in trawled areas [61,62,90]. Third, stations coordinates of the PCAs based on both surface sediment and SPI characteristics correlated significantly with BSS, but not BTE. Fourth, the incorporation of BTE with BSS in multiple regression models did not improve the description of either the surface sediment or the SPI characteristics assessed during the present study. None of the correlations that were not significant using BSS alone as the independent variable became significant when incorporating BTE as a second independent variable. Moreover, for most characteristics correlating significantly with BSS alone (i.e., all except tube number and total number of biological traces), the incorporation of BTE resulted in poorer descriptions. Therefore, BTE 
did not account as well for changes in surface sediment and SPI characteristics assessed not described by changes in BSS.

Overall, the only rationale for a significant impact of bottom trawling was the sometimes high (i.e., up to ca $80 \%$ ) proportion of SPI featuring trawling traces. However, these proportions were highly variable between stations and did not correlate significantly with BTE. Moreover, the trawling traces recorded during the present study almost exclusively consisted in mud clasts with almost no furrows and no puzzle fabrics at all. This is an important point, since the direct causality linking bottom trawling and the presence of mud clasts appears still questionable [91,92]. For example, similar proportions of SPI featuring trawling traces (including mud clasts) have been reported in several areas of the Gulf of Lions experimenting different BTE $[61,62,93]$, which further highlights the difficulty in unambiguously associating the presence of mud clasts with bottom trawling.

Based on these rationales, our overall conclusion is that the assessment of the spatial distributions of both SPI characteristics and BTE recorded during the present study does not support the hypothesis according to which bottom trawling is a key factor in controlling the spatial structuration of the WGMP. However, it should be pointed out that this conclusion may partly result from differences in spatial scales associated with the assessments of BTE (i.e., a few $\mathrm{km}^{2}$ ) and SPI characteristics (i.e., typically a few $\mathrm{m}^{2}$ ). BTE is known to induce spatially heterogeneous effects on benthic habitats even within experimentally heavily trawled areas [94], which led Smith et al. [95] to recommend collecting a high number of SPIs (i.e., ca. 30, which is much more than achieved during the present study) at each station to infer the impact of bottom trawling (see also [86,96], for the interest of complementary approaches). BTE was not spatially homogeneous over each of the $1.77 \mathrm{~km}^{2}$ cells considered during the present study, which may have hampered the detection of significant correlations between BTE and both surface sediment and SPI characteristics measured over much smaller spatial scales. Differences in temporal scales associated with the assessment of BTE (i.e., one year during the present study) and the kinetics of recovery of benthic habitats may have had the same effect as well.

\subsection{Comparison with the Rhône River Prodelta}

\subsubsection{Surface Sediment Characteristics}

$\delta^{13} \mathrm{C}$ values differed between the distal part of the WGMP and the Rhône River Prodelta (RRP) regarding both their absolute values and their changes relative to station depth. In the RRP, $\delta^{13} \mathrm{C}$ ranged from $-24.2 \%$ to $-27.2 \%$ and significantly increased with station depth, whereas in the distal part of the WGMP, they were close to $-23 \%$ and did not change significantly with station depth. In the RRP, these results have been interpreted as reflecting the dominance of a continental source of organic matter and its gradual mixing with marine sources through a series of resuspension/sedimentation events occurring within the prodelta itself $[74,81,97-99]$. In the WGMP, $\delta^{13} \mathrm{C}$ values around $-23 \%$ have been reported in suspended particulate material both at the Mouth of the Gironde Estuary and in the inner part of the Bay of Biscay Continental Shelf [100]. These values were interpreted as resulting from an early mixing between (1) a continental/terrestrial source (with a mean $\delta^{13} \mathrm{C}$ of $-25.9 \%$ ), (2) estuarine sources generated by autochthonous processes due to long estuarine residence times [101,102], and (3), a marine planktonic source (with a mean $\delta^{13} \mathrm{C}$ of $-20.5 \%$ ). Such an early mixing within the Gironde Estuary is largely resulting from its macro-tidal regime $[100,103]$. Our own results support this interpretation and suggest the lack of subsequent significant mixing with marine sources in the WGMP itself. Overall, the discrepancies in the $\delta^{13} \mathrm{C}$ between the two systems are indicative of major differences in the timing and the nature of the processes involved in the mixing of continental and marine sources of sedimented Particulate Organic Matter (POM).

Our results show a lack of correlation between station depth and $\mathrm{D}_{0.5}$ and the presence of coarser sediment in the distal part of the WGMP, despite a lower water discharge and a long (i.e., 1-2 years in the Estuarine Turbidity Maximum) particle residence time in the Gironde Estuary $[104,105]$. There were also marked differences between systems 
in both sedimentary organics concentrations and their changes relative to station depth. THAA concentrations were higher in the WGMP, where they increased with station depth conversely to what was observed in the RRP. Such opposite patterns were also observed for POC and, to lesser extent, EHAA. In the RRP, spatial changes in $\mathrm{D}_{0.5}$ and surface sediment concentrations were interpreted as resulting from (1) a particle sorting relative to size induced by the succession of sedimentation/resuspension events [106] and (2) the progressive dilution of a highly dominant continental POM source originating from the Rhône River [55,56,74,81,97-99]. The Gironde River is also the dominant source of particles fueling the WGMP $[31,32,41]$, and successive sedimentation/resuspension events are largely responsible for the transfer of particles at depth in this system as well [26]. Therefore, the same two key driving factors are inducing major differences in the spatial structuration of the two systems. The lack of depth gradient in particle size in the distal part of the WGMP suggests that particle sorting is not predominantly controlled by particle size in the WGMP. Density may constitute an alternative sorting cue as suggested by the preferential sedimentation of denser particles following major resuspension events [43]. In coastal sediments, low-density particles are organically enriched and behave similar to smaller ones with regard to particle sorting [107]. Therefore, a density-driven particle sorting could account for the depth gradients observed in the distal part of the WGMP; low-density (and organically enriched) particles being preferentially settled and trapped in deeper areas irrespective of their size, which would account for increasing bulk organic concentrations with station depth. At this stage, this only constitutes a working hypothesis, and it will certainly prove interesting to assess spatial changes in the proportion of lowdensity particles during future studies taking place in the WGMP.

EHAA/THAA ratios were lower in the distal part of the WGMP than in the RRP. This is indicative of a lower lability of sedimented POM, which may be linked to the long residence time of particles in the Gironde Estuary [104,105] and the predominance of degradation processes in its Estuarine Turbidity Maximum [101,108-110]. Conversely Chl- $a /(\mathrm{Chl}-a+$ Phaeo- $a$ ) ratios did not significantly differ between areas. These two indices showed the same pattern of change relative to station depth in both systems with (1) a significant decrease in Chl- $a$ /(Chl- $a+$ Phaeo- $a$ ) ratios and (2) no significant change in EHAA/THAA ratios. In the RRP, the discrepancy between the two indices has been attributed to the fact that the Chl- $a$ / (Chl- $a+$ Phaeo- $a$ ) ratio is representing a highly labile vegetal fraction of the sediment POM, whereas the EHAA/THAA ratio is representative of the lability of the bulk nitrogenous fraction of sedimentary organics [56,57]. This suggests that both in the WGMP and the RRP, degradation processes occurring during the transfer of deposited particles at depth are mostly affecting a highly labile fraction of POM. Since this component is contributing only to a small fraction of bulk sedimentary organics, this is also in agreement with the lack of significant changes in $\delta^{13} \mathrm{C}$ with station depth.

Overall, the WGMP and RRP present strong similarities. Both are alimented by particles originating from major rivers. Moreover, the transfer of particles along their depth gradient is cued by sorting processes associated with the succession of sedimentation and resuspension sequences. Major differences between the two systems first refer to the tidal regime and marine hydrodynamics, which result in a much earlier mixing between continental and marine POM in the Gironde estuarine system. More specifically, this mixing is largely taking place in the RRP itself and conversely upstream the WGMP, namely in the Gironde Estuary and near its mouth. Other major differences between the two systems are linked to sedimentary organic concentrations and their patterns of change relative to station depth. We hypothesized that this may result from different particle sorting processes (i.e., mostly cued by particle size and particle density in the RRP and the WGMP, respectively) associated with successive sedimentation/resuspension events. These differences support the distinction between type 1 and type 2 prodeltas [3,5] for temperate areas. 


\subsubsection{Bioturbation}

In both systems, the aRPD thickness, the total number of biological traces, and the thickness of the bioturbated layer increased with station depth in accordance with the negative impact of disturbance on bioturbation described by the Pearson and Rosenberg [111] and Rhoads et al. [12] models. However, the nature of the dominant disturbance itself differs between systems. In the RRP, the shallowest stations are mostly submitted to high sedimentation rates $[74,79,80,112]$ and associated organic matter inputs caused by river floods [56]. This results in sediment instability and organic enrichment, which largely affect benthic macrofauna composition and limit bioturbation [56]. In the distal part of the RRP, continental inputs are diluted and sediment stability is higher, which results in increasing bioturbation. In the proximal part of the WGMP, strong Bottom Shear Stress (BSS) precludes modern sedimentation $[25,26]$. It also largely controls the composition of resident fauna, which is largely dominated by suspension feeders (mostly the small-sized bivalve Kurtiella bidentata and the ophiuroid Amphiura filiformis; [45]) that are not efficient bioturbators under such environmental conditions.

There were also important differences in bioturbation between the distal parts of the WGMP and the RPP. These differences refer both to overall intensity and change relative to station depth. In the distal part of the WGMP, bioturbation intensity tended to increase with station depth together with decreasing BSS, which is coherent with the Rhoads et al. [12] model. Conversely, in the distal part of the RRP, there was no clear correlation between station depth and bioturbation intensity. Salen-Picard et al. [113] reported the existence of a positive impact of Rhone River floods on the abundance of subsurface feeders (i.e., potentially strong bioturbators) at a $70 \mathrm{~m}$ deep station with a time lag of ca. 33 months. Therefore, the lack of significant correlation between bioturbation intensity with station depth in the distal part of the RRP may result from opposite gradients in three potentially controlling factors, namely: (1) organic matter availability, which decreases with station depth; (2) the positive impact of floods on the abundance of strong bioturbators, which also decreases with station depth; and (3) sediment stability, which conversely increases with station depth. According to this hypothesis, the lack of gradient in bioturbation intensity in relation with station depth would result from an equilibrium between organic matter availability and sediment stability and therefore conforms to the Rhoads et al. [12] model.

Differences between overall bioturbation intensities between systems are not easy to account for. According to the Rhoads et al. [12] model, bioturbation intensity results from the interaction between organic matter availability (eventually through its effect on benthic macrofauna) and physical disturbances [12]. POC sediment concentrations were quite similar in both areas, which was also true for amino acid concentrations when accounting for their bioavailability (i.e., EHAA). The comparison of benthic macrofauna abundance, biomass, and feeding types between systems is clearly complicated by the fact that they were not sampled using the same gear (i.e., an Hamon grab for Massé et al. [45] vs. a Van Veen grab for Bonifacio et al. [56]. Nevertheless, it showed no obvious difference in the nature and abundance of major potential bioturbators. During the present study, we considered the effect of hydrodynamics, sedimentation, and bottom trawling as potential sources of physical disturbances within the WGMP. Therefore, these three sources of physical disturbances could also account for differences between systems. As exemplified by differences in (1) WGMP and RRP morphologies [5], and (2) the upper depth limit allowing for modern sedimentation $[25,26,114]$, hydrodynamics is stronger in the WGMP and therefore cannot directly account for higher bioturbation intensity in this area. Conversely, sedimentation rates are higher in the RRP; however, they decrease with depth to reach ca. $0.63 \mathrm{~cm} \cdot \mathrm{y}-{ }^{1}$ at $73 \mathrm{~m}[114,115]$, which is close to the sedimentation rates (i.e., between 0.15 and $0.50 \mathrm{~cm} . \mathrm{y}-{ }^{1}$ ) recorded in the WGMP between 45 and $71 \mathrm{~m}[25,26]$. Therefore, it is unlikely as well that differences in sedimentation can account for differences in bioturbation intensity between systems. Automatic Identification System (AIS) data collected by Global Fishing Watch [69,70] are available only since 2012. Therefore, we computed the spatial distribution of BTE in the Rhône River for the June 2017-June 2018. 
Results (available on request to B.L.) showed an overall higher (i.e., by a factor of 2.3) BTE in the RRP than in the WGMP. However, the spatial distribution of BTE clearly differed between systems. BTE was maximal in the shallowest part of the RRP and then decreased with depth so that it was not higher in the distal part of the RRP than in the WGMP. Assuming stability in BTE in the RRP between 2007 and 2017, therefore, our conclusion is that differences in the intensity of the physical disturbance caused by bottom trawling are probably not responsible for differences in bioturbation intensity between systems as well.

Overall, the identification of the cause of difference in bioturbation intensities between the WGMP and RRP distal parts will clearly require additional studies. There are several ways forward: (1) the comparative assessment of sediment mechanical properties (Dorgan et al. [116]) in both systems, (2) the refinement of the comparison of benthic macrofauna composition through the use of the same sampling gear (see above), and (3) considering the temporal dynamics of bioturbation in both systems. Within the WGMP, Jouanneau et al. [35] indeed described the alternation of calm periods during which bioturbation is high and periods following strong storms during which bioturbation traces are destroyed. Along the same line, Bonifacio et al. [56] showed that river floods induce a quick (i.e., within 1-2 months) change in bioturbation within the RRP. Considering possible impacts of temporal dynamics may be important as well for all parameters/processes considered during the present study. This could be tackled by seasonally sampling along a depth gradient as already achieved for the RRP by Bonifacio et al. [56].

\section{Conclusions}

Our results first support the spatial subdivision of the West Gironde Mud Patch (WGMP) in a proximal and a distal part. They also show the existence of depth gradients in surface sedimentary organics characteristics and bioturbation within the distal part and suggest that these gradients are more related to hydrodynamics than bottom trawling. The comparison with the Rhône River Prodelta finally highlights major discrepancies. These discrepancies refer to (1) the mixing of continental and marine sources of particulate organic matter that is taking place in the Gironde Estuary versus the Rhône River Prodelta itself, and (2) opposite patterns of changes in sedimentary organic concentrations relative to depth, which may result from particle sorting processes during sedimentation/resuspension cycles mainly cued by particle size in the Rhône River Prodelta and density in the WGMP. Overall, our results support the distinction between type 1 and type 2 river-dominated ocean margins $[3,5]$ in temperate areas.

Author Contributions: Conceptualization, B.L., B.D. and A.G.; Data curation, B.L.; Formal analysis, B.L. and A.G.; Funding acquisition, B.D. and A.G.; Investigation, B.L., B.D., S.S., N.D., G.B. and A.G.; Methodology, B.L., B.D., S.S., M.D., F.G. (Florent Grasso), A.S., H.G. and A.G.; Project administration, A.G.; Resources, B.L., B.D., A.G.D., S.S., A.R.-R., F.G. (Frédéric Garabetian), N.D., M.D., F.G. (Florent Grasso), A.S., G.B., H.G., M.-A.C., D.P., P.L., H.D., M.D. and M.M.B.T.; Software, B.L., A.G.D., A.R.-R., M.D., F.G. (Florent Grasso) and H.G.; Validation, B.L., B.D. and A.G.; Visualization, B.L. and A.G.; Writing—original draft, B.L. and A.G.; Writing—review and editing, B.L., B.D., S.S., A.R.-R., F.G. (Frédéric Garabetian), F.G. (Florent Grasso), A.S., G.B. and A.G. All authors have read and agreed to the published version of the manuscript.

Funding: This work is part of the PhD thesis of Bastien Lamarque (Bordeaux University). Bastien Lamarque was partly supported by a doctoral grant from the French "Ministère de l'Enseignement Supérieur, de la Recherche et de l'Innovation". This work was supported by: (1) the JERICO-NEXT project (European Union's Horizon 2020 Research and Innovation program under grant agreement no. 654410), (2) the VOG project (LEFE-CYBER and EC2CO-PNEC), and (3) the MAGMA project (COTE cluster of Excellence ANR-10-LABX-45). It also benefited from additional fundings allocated by the Conseil Régional Nouvelle-Aquitaine and the Agence Française de la Biodiversité. Operations at sea were funded by the French Oceanographic Fleet.

Data Availability Statement: The data presented in this study are available in SEANOE at https: / / doi.org/10.17882/78991, [117]. 
Acknowledgments: The authors wish to thank the crew of the R/V Côtes de la Manche for their help during field sampling, Céline Labrune for sharing Rhône River Prodelta SPI data, and Marie Claire Perello and Pierre Touzerie for their help in the analysis of some samples and results.

Conflicts of Interest: The authors declare no conflict of interest. The funders had no role in the design of the study; in the collection, analyses, or interpretation of data; in the writing of the manuscript, or in the decision to publish the results.

\section{Appendix A}

Table A1. Location (WGS84, degrees, and decimal minutes) and depth of the 32 sampled stations, with associated mean values ( \pm standard deviation) of surface sediment and SPI characteristics, and Bottom Trawling Effort within cells containing stations. Station positionings are shown in Figure 1. D0.5: median grain size, SSA: Sediment Surface Area, POC: Particulate Organic Carbon, Chl-a: Chlorophyll-a, Phaeo-a: Phaeophytin-a, THAA: Total Hydrolyzable Amino Acids, EHAA: Enzymatically Hydrolyzable Amino Acids, aRPD: apparent Redox Potential Discontinuity thickness, Burrows: number of burrows, OV: number of oxic voids, OV depth: maximal depth of oxic voids, Tubes: number of tubes, Feeding pits: number of feeding pits, Epifauna: number of epifauna, Infauna: number of infauna, Clasts: number of clasts, Furrows: number of furrows, BSS: 95th percentile of Bottom Shear Stress, BTE: Summed Bottom Trawling Effort.

\begin{tabular}{|c|c|c|c|c|c|c|c|c|c|c|c|c|c|c|c|c|c|c|c|c|c|c|c|c|c|c|}
\hline $\begin{array}{l}\text { sation } \\
\text { Salo }\end{array}$ & $\begin{array}{l}\text { Litude } \\
\mathrm{N}\end{array}$ & $\begin{array}{l}\text { Longitidue } \\
\text { we }\end{array}$ & 衣epht & 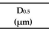 & 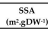 & 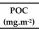 & 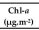 & 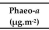 & 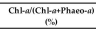 & 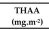 & 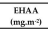 & 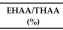 & 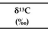 & $\begin{array}{l}\text { Number } \\
\text { of fort }\end{array}$ & $\begin{array}{c}\text { aRPD } \\
\text { Immi } \\
\text { Ims }\end{array}$ & 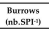 & 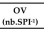 & 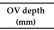 & 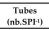 & 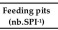 & 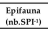 & 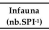 & 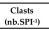 & 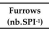 & 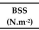 & 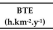 \\
\hline 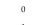 & $4594.466^{16}$ & 1299016 & 325 & 46.6285 & $4.8 \pm 0.3 .3$ & $12: 0.1$ & 0.15 & 0.62 & 199 & $0.25 \pm 0.001$ & $0.05=0.000$ & $217 \geq 13$ & $.232 \pm 0.1$ & 6 & $2016 \pm 127$ & $25+12$ & $22+1 s$ & $70: 8 \pm 477$ & $3.5 \pm 3.0$ & 0.000 .0 .0 & $05 \pm 05$ & $1.2 \pm 12$ & $0.0 \pm 0.0$ & $0.0 \pm 0.00$ & 1.1 & \\
\hline 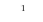 & $4545.580^{\circ}$ & ${ }^{133.1,459}$ & ${ }_{37}$ & $173+1.1$ & $10.7 \pm 0.7$ & 1.5 a.a. & 0.26 & 0.71 & 266 & $0.27 \pm 0.01$ & $0.015 \pm 0.01$ & $19.0 \pm 0.7$ & -23.5 & 。 & 23.015150 & $1.2 \pm 0.8$ & 070.5 & $399 \pm 462$ & $33 \pm 1.9$ & 0.00 .0 .0 & $05 \pm 0.8$ & ${ }_{1.0 \pm 13}^{1.03}$ & $0.0 \pm 0.0$ & $0.0 \pm 0.0$ & 1 & 37 \\
\hline${ }^{2}$ & $45435.511^{\prime \prime}$ & ${ }_{103773}$ & 478 & $24 s+1.4$ & $6.1 \pm 0.2$ & 1.0. 0.1 .1 & 0.36 & 1.54 & 19.2 & $0.36+0.044$ & $0.99=0.000$ & $245 \pm 13$ & .229+0.090 & 6 & $697 \geq 2.2$ & $3 s \pm 0.8$ & $38 \pm 25$ & $1198 \pm 20.5$ & $32 \pm 1.6$ & 0.00 .0 .0 & $02 \geq 0.4$ & $0.8 \pm 0.8$ & $02 \pm 0.4$ & $0.0 \pm 0.0$ & 0.8 & 29 \\
\hline & ${ }^{454+1.60^{\prime \prime}}$ & 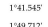 & 565 & 190.0 .0 .1 & $87 \pm 0.2$ & $13 \pm 0.0 .0$ & 0.28 & 1.2 & 188 & $0.46 \pm 0.03$ & $0.088 \pm 0.000$ & 1700005 & $.23 .1 \pm 0.3$ & 6 & $749=9,6$ & $32 \pm 15$ & $52 \pm 49$ & $1378 \pm 284$ & $40 \pm 2.5$ & $0.3 \pm 0.5$ & $03 \pm 0.5$ & $1.0 \pm 0.9$ & $13 \pm 23$ & $0.0 \pm 00$ & 0.6 & 49 \\
\hline 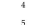 & 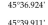 & 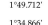 & 7.5 & $\begin{array}{l}173 \pm 0.66 \\
103010\end{array}$ & $9.8 \pm 0.5$ & $1.5 \pm 0.1$ & 0.31 & 176 & 151 & $0.58=0.000$ & $0.10=0.01$ & $17: 022.4$ & $-226 \pm 0.4$ & 6 & $1013+18.8$ & $3.0 \pm 1.1$. & ${ }^{68 . \pm 24}$ & $1333+150$, & $9,5 \leq 6.1$ & $07=0.5$ & $0.0 \pm \pm 0.0$ & $0.2 \pm 0.4$ & $23+23$ & $0.0 \pm 000$ & 0.5 & 3 \\
\hline 5 & 4559911 & 1"34:868" & 455 & $193 \pm 19$ & $8.2 \pm 0.1$ & $1.3 \pm 0.2$ & 0.33 & 129 & 2013 & ntata & mas & wha & $-232 \pm 0.00$ & 5 & $61.9=5.57$ & $32 \pm 0.4$ & $34 \pm 18$ & $1069 \pm 564$ & $26: 22$ & $0.0=0.00$ & $0.0 \pm 000$ & $1.6 \pm 1.13$ & $32 \pm \pm 3$ & $0.0 \pm 00$ & ${ }^{0.8}$ & 5 \\
\hline$\therefore$ & 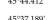 & 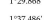 & 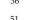 & $298 \pm 0.88$ & 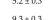 & $0,7=0.2$ & 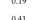 & . & ${ }^{23}$ & n/a & na & n/a & -222.2 & 6 & $\begin{array}{l}35 \pm 3.00 \\
830.40\end{array}$ & $0.8 \pm 13$ & $0.5 \pm 08$ & 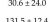 & 6.3 .4 .8 & 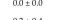 & ${ }^{202 \pm 04}$ & ${ }_{0.5 \pm 0.5}$ & 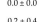 & $000 \pm 00$ & 1 & 23 \\
\hline & 45.58773 & 10.577 & 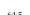 & 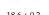 & 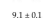 & $14+01$ & 0.03 & 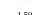 & , & . & ma & ma & 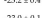 & & 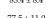 & 年 & 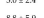 & 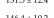 & 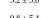 & 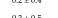 & a & 13.10 & tantut & 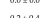 & 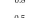 & 5 \\
\hline & & & 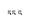 & & 9. & 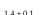 & 035 & (1) & 50 & 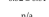 & . & . & 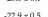 & & 3 & 23 & 110 & 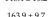 & 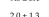 & . & 年 & 年 & & 年 & of & 88 \\
\hline 10 & (4) & 1024897 & 125 & $268+10$ & $54+08$ & $13+0$. & 015 & 0.87 & 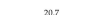 & $0.188 \mathrm{tmom}$ & $0.05 \times 0.00$ & $266+20$ & $229+05$ & 6 & 307.67 & $25+10$ & 27273 & 6390.386 & $18+12$ & $07=08$ & $02 \geq 01$ & $27+21$ & $02+04$ & $00+00$ & 09 & ${ }^{52}$ \\
\hline 2.3 & 42268\% & $1999646+6$ & 515 & $2000 \pm 0.4$ & $8.1 \pm 0.1$ & $12 \pm 0.1$ & 0.32 & 1.44 & 182 & $0.49 \pm 000$ & $0.10 \pm 0.000$ & 207712 & $-231 \pm 00$ & 6 & $699 \pm 109$ & 30.14 & $20 \pm 30$ & $1320 \pm 203$ & $27 \pm 2.3$ & 00000 & $00 \pm 00$ & ${ }_{17 \neq 15}$ & $08 \pm 08$ & $0.00 \pm 00$ & 07 & 4 \\
\hline & $4599999^{\prime}$ & $1^{149352}$ & 605 & $19.1+0.5$ & 73.03 & $12 \geq \pm .1$ & 0.09 & 1.65 & 29.1 & $0.47 \pm 0.009$ & $0.11=0.00$ & 26612 & 23110.5 & 6 & 244.95 & $32+17$ & $80 \pm 33$ & $1403+233$ & $85: 43$ & $0,0=0.0$ & $000 \pm 0.0$ & ${ }_{1.0 \pm 1.1}$ & $23+23$ & $0.00 \pm 00$ & 06, & 194 \\
\hline & 7.984 & 1847529 & 675 & $224+24$ & 7.1.1.1.2 & $14+02$ & 0.4 & 1.71 & 19 & $0.52+0.04$ & $0.11=0.01$ & $212: 203$ & $229 \pm 0.00$ & 6 & $81.1=11.0$ & $3 s+10$ & $130: 522$ & $140+4+127$ & $103+72$ & $0.5=0.5$ & $000+000$ & $13+1.4$ & $25+23$ & $0.0 \pm 0.00$ & 0.5 & $5_{4}$ \\
\hline A & 4537254 & $1945 \mathrm{Sg}$ & 62 & 22001.4 & 677002 & $17 \geq 0.1$ & 0.46 & 299 & 132 & n/a & nia & n/a & . & 5 & 843553 & $4.4+15$ & 96034 & $13982+199$ & $5.6 \pm 3.33$ & 0220.4 & $00 \pm 000$ & ${ }_{1.6113}$ & $22+23$ & $0.2 \pm 0.4$ & 05 & 76 \\
\hline AE & $455_{42,035}$ & 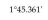 & 61 & $105 \pm 13$ & 8771.3 & $1.5 \pm 0.1$ & 0.4 & 1.77 & 19.9 & $\mathrm{n} / \mathrm{a}$ & n/a & n/a & $.228 \pm 0.4$ & 5 & $75.6 \pm 1.6$. & $38 \pm .1$. & $108: 399$ & $1613 \neq 88$ & $52 \pm 377$ & $0.2 \pm 0.4$ & $0.0 \pm 000$ & $0.4 \pm 0.9$ & $0.2 \pm 0.4$ & $0.0 \pm 0.0$ & 0.6 & 28 \\
\hline${ }_{A F}$ & 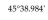 & 1940254 & 556 & $215 \pm 0.1$. & 7.6.a.1 & $1.4 \pm 0.1$ & 0.35 & 1.37 & 203 & n/a & nia & n/a & .2200102 & 6 & 77.129 .6 & 30.006 & $100 \pm \pm 7.1$. & 144.15379 & $1.2 \pm 0.4$ & $0.0 \pm 0.0$ & $02 \pm 0.4$ & $0.0 \pm \pm 0.0$ & $0.3 \pm 0.8$ & $0.00 \pm 0.00$ & 0.7 & 26 \\
\hline${ }^{A K}$ & 455431919' & 1924.727 & 555 & $2065+000$ & 76.0 .66 & $13 \pm 00$ & 0.37 & 1.54 & 19.4 & $\mathrm{~N} / \mathrm{a}$ & n/a & n/a & $.230 \pm 0.3$ & 4 & $623=26262$ & $33 \pm 1.10$ & $113+57$ & $1325 \pm 234$ & $3.8 \pm 1.9$ & 0.020 .0 .0 & $00 \pm 00$ & $18 \pm 1.0$ & $13 \pm 1.9$ & $0.0 \pm 0.00$ & 0.6 & 43 \\
\hline AL & $454.77 x^{4}$ & 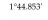 & 58 & $20.4 \pm 17$ & 6.30 .55 & $1.2 \pm 0.2$ & 0.27 & 1.44 & 158 & $n / a$ & n/a & $n / a$ & $-228 \pm 05$ & 6 & $74.4 \pm 121$ & $27 \pm 1.0$ & $98 \pm 43$ & $1480 \pm \pm 126$ & $132 \pm+11.9$ & $0.2 \pm 0.4$ & $00 \pm 00$ & $0.2 \pm 0.4$ & $0.7 \pm 0.8$ & $0.00 \pm 0.0$ & 0.6 & 8.1 \\
\hline${ }^{A N}$ & & $198.1000^{\circ}$ & ${ }_{585}$ & $210 \pm 18$ & & & 0.78 & 1.8 & 30.2 & $\mathrm{n} / \mathrm{a}$ & $\mathrm{n} / \mathrm{a}$ & $\mathrm{n} / \mathrm{a}$ & .2260 .1 .1 & 6 & $749: 9145$ & 35.524 & $107 \pm 21$ & $1472 \pm 224.8$ & $3.5 \pm 2.2$ & $0.0 \pm 0.0 .0$ & $0.0 \pm \pm 0.0$ & & $28 \pm 29$ & $0.0 \pm 0.00$ & 0.6 & 0.5 \\
\hline $\mathrm{AO}^{2}$ & ${ }^{4545,5522^{2}}$ & $1+20.1070$ & i.05 & $212 \pm 0.3$ & $8.3 \pm 0.1$ & $12 \geq 0.1$ & 0.33 & 1.15 & 222. & $\pi / a$ & $\mathrm{n} / \mathrm{a}$ & nia & $.228 \pm 0.4$ & ${ }^{6}$ & $72.9 \pm 14$ & $23 \pm 08$ & 8773.1. & $1334 \pm 3472$ & $3,0 \pm 4,0$ & $0.33 \pm 0.8$ & $10 \pm 0.6$ & $1.2 \pm 0.8$ & 07712 & $0.0 \pm 0.00$ & 0.7 & \\
\hline s. & 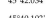 & 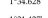 & ${ }^{435}$ & $2026 \pm 1 /$ & $7,9=0.03$ & Dit & 233 & 1.05 & 7,79 & was & naa & naa & 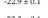 & 6 & $871=9,2$ & $25 \mathrm{tat}$ & 60 & $1327+7=1$ & $37=27$ & $0.22=0.4$ & 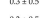 & $0.5+0.5$ & $28 \times 26$ & $0.0+0.00$ & 等 & $3^{3}$ \\
\hline Av & 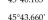 & (3) & 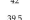 & 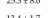 & 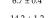 & D.t. & 0.2 & 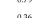 & 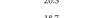 & was & as & wa & - & $\therefore$ & 舟 & 年 & $2=032$ & 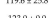 & $=0$ & 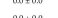 & 然 & (12) & 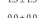 & 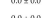 & 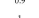 & 14 \\
\hline iw & 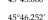 & 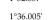 & 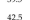 & 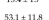 & 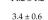 & 13:07 & 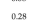 & 108 & 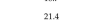 & , & , & a & 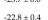 & 6 & 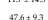 & 2013 & 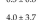 & 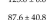 & 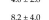 & 急 & 年 & 年 & 年 & . & 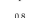 & , \\
\hline$A x$ & 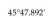 & 1139657 & 47 & $101 \pm 07$ & $72 \pm 06$ & 1. & 0.64 & 289 & 181 & 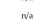 & we & wa & 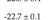 & & $\{18: 39$ & $30+18$ & 50 & $x_{3}$ & 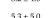 & $02=04$ & 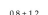 & 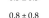 & $5=08$ & 年 & 07 & 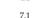 \\
\hline$A Y$ & & 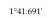 & & & & & $0: 11$ & & 18.6 & 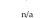 & 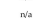 & . & 12 & & 9 & 38,18 & 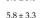 & 0 & & & & & $08+10$ & 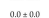 & & 11 \\
\hline${ }_{B \mathrm{BK}}$ & & $1 \% 1705$ & 58 & & $66+00$ & & tha & . & mas & wa & nia & a & & 6 & 64 & 16 & $73+29$ & 67 & $52,+41$ & & & & $3+05$ & $000+00$ & 0,6 & 122 \\
\hline $\mathrm{FG}$ & 4595,524 & $1^{150.684}$ & $n 15$ & 2005 & $73 \pm 0.1$ & $16 t 0.1$ & 028 & 1.64 & 14.4 & wa & wa & wa & $.230 \pm 01$ & 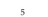 & $834 \pm 151$ & $2: 409$ & $8 . t$ & $1322+69$ & $128+72$ & & $0_{t+1}$ & $12+0.8$ & $1.4+1.7$ & $0.0 \pm 00$ & 0.5 & ne \\
\hline & $453295 \mathrm{C}^{\circ}$ & ${ }_{1054563}$ & 79 & $178+05$ & $8.6=0.3$ & $21 \pm 0.3$ & 0.59 & 308 & 147 & $w_{a}$ & /a & n/a & $.228 \pm 0.1$ & 8 & $993=176$ & $35 \pm 08$ & $1014 \pm 39$ & $1995+254$ & 61 & 0,4, & & & $1.4+20$ & $00 \pm 00$ & 0.4 & 36 \\
\hline n & $36,626^{6}$ & $1^{10877771}$ & 655 & $2400 t$ & 0.2 & 160 & 0.22 & 1.44 & . & w/a & N/a & wa & - $2327+0$. & 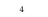 & $578: 132$ & $40+18$ & $1800 \pm 22$ & 1.199 .3 & $115+39$ & $0.5=$ & oot. & $0.8 \pm 1.5$ & $6.8 \pm 6.4$ & $0.00+00$ & 0.5 & 10.1 \\
\hline ss & 4533064 & 15928063 & 78 & $2077+0.1$ & $7,6: 004$ & $19 \pm 02$ & $0.4+$ & 246 & 15.1 & 0.6980 .05 & Na & Na & .229003 & 6 & $882=144$ & $23+16$ & $112+58$ & $1431+189$ & $103 \pm 73$ & $0,0=0.0$ & $00 \pm 000$ & $0,5=0.8$ & $48 \pm 50$, & 00000 & 0.4 & 92 \\
\hline
\end{tabular}

\section{Appendix B}

Table A2. Determination coefficients $\left(\mathrm{R}^{2}\right)$, associated probability levels $(p)$, slopes and intercepts of the simple linear regression models linking station depth and assessed parameters within: (1) the whole WGMP and (2) its sole distal part. Bold types are indicative of significant $(p<0.05)$ correlations and underlined types correspond to simple linear regression models without the outliers constituted by stations AN and 3_8.

\begin{tabular}{|c|c|c|c|c|c|c|c|c|c|c|c|}
\hline & & \multicolumn{5}{|c|}{ Whole WGMP } & \multicolumn{5}{|c|}{ Distal area } \\
\hline & & $\mathrm{n}$ & $\mathrm{R}^{2}$ & $\mathrm{p}$ & Slope & Intercept & $\mathrm{n}$ & $\mathrm{R}^{2}$ & $\mathrm{p}$ & Slope & Intercept \\
\hline \multirow{10}{*}{ 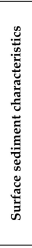 } & $\begin{array}{lll}D_{0,5} \\
\text { Scs }\end{array}$ & 32 & 0.182 & 0.015 & -0.358 & 42.362 & 25 & 0.021 & 0.493 & & \\
\hline & SSA & 32 & 0.013 & 0.533 & & & 25 & 0.008 & 0.678 & & \\
\hline & POC & 32 & 0.578 & $<0.001$ & 0.019 & 0.290 & 25 & 0.720 & $<0.001$ & 0.022 & 0.131 \\
\hline & $\mathrm{Chl}-a$ & 31 & 0.207 & 0.010 & 0.006 & 0.040 & $\begin{array}{l}24 \\
22 \\
\end{array}$ & $\begin{array}{l}0.008 \\
0.011\end{array}$ & $\begin{array}{l}0.682 \\
0.638 \\
0.638\end{array}$ & & \\
\hline & Phaeo-a & 31 & 0.485 & $<0.001$ & 0.039 & -0.580 & $\begin{array}{l}24 \\
22 \\
\end{array}$ & $\begin{array}{l}0.185 \\
0.187 \\
\end{array}$ & $\begin{array}{l}0.036 \\
0.044\end{array}$ & $\begin{array}{l}0.024 \\
0.024\end{array}$ & $\begin{array}{l}0.350 \\
0.347 \\
\end{array}$ \\
\hline & Chl- $a /$ (Chl- $a+$ Phaeo- $a)$ & 31 & 0.190 & 0.014 & -0.144 & 26.990 & $\begin{array}{l}24 \\
22\end{array}$ & $\begin{array}{l}0.107 \\
0.385\end{array}$ & $\begin{array}{l}0.118 \\
0.002\end{array}$ & -0.147 & 26.125 \\
\hline & THAA & 11 & 0.873 & $<0.001$ & 0.010 & -0.113 & 8 & 0.850 & 0.001 & 0.009 & -0.028 \\
\hline & EHAA & 10 & 0.638 & 0.006 & 0.001 & 0.006 & 7 & 0.089 & 0.515 & & \\
\hline & EHAA/THAA & 10 & 0.218 & 0.174 & & & 7 & 0.301 & 0.202 & & \\
\hline & ${ }^{81 \mathrm{C}} \mathrm{C}$ & 32 & 0.041 & 0.267 & & & 25 & 0.021 & 0.492 & & \\
\hline \multirow{9}{*}{ 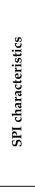 } & aRPD thickness & 32 & 0.598 & $<0.001$ & 1.531 & -18.413 & 25 & 0.329 & 0.003 & 0.695 & \\
\hline & Number of burrows & 32 & 0.255 & 0.003 & 0.034 & 1.034 & 25 & $<0.001$ & 0.903 & & \\
\hline & Number of oxic voids & 32 & 0.578 & $<0.001$ & 0.262 & -7.139 & 25 & 0.303 & 0.004 & 0.193 & -2.743 \\
\hline & Maximal depth of oxic voids & 32 & 0.498 & $<0.001$ & 1.892 & 21.080 & 25 & 0.241 & 0.013 & 0.679 & 97.223 \\
\hline & Number of feeding pits & 32 & 0.194 & 0.012 & 0.009 & -0.260 & 25 & 0.168 & 0.042 & 0.009 & -0.319 \\
\hline & Number of tubes & 32 & 0.351 & $<0.001$ & 0.169 & -3.512 & 25 & 0.433 & $<0.001$ & 0.244 & -8.228 \\
\hline & Number of epifauna & 32 & 0.133 & 0.040 & -0.013 & 0.961 & 25 & 0.174 & 0.038 & -0.020 & -0.020 \\
\hline & Number of infauna & 32 & 0.053 & 0.204 & & & 25 & 0.022 & 0.475 & & \\
\hline & $\begin{array}{c}\text { Total number of biological } \\
\text { traces }\end{array}$ & 32 & 0.654 & $<0.001$ & 0.449 & -7.325 & 25 & 0.479 & $<0.001$ & 0.419 & -5.418 \\
\hline$\stackrel{\infty}{\infty}$ & BSS 95"t percentile & 32 & 0.926 & $<0.001$ & -0.014 & 1.469 & 25 & 0.908 & $<0.001$ & -0.012 & 1.324 \\
\hline \multirow{2}{*}{ 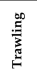 } & $\begin{array}{c}\text { Summed Bottom Trawling } \\
\text { Effort }\end{array}$ & 32 & 0.180 & 0.016 & 0.138 & -2.267 & 25 & 0.090 & 0.147 & & \\
\hline & $\begin{array}{l}\text { Proportion of SPI featuring } \\
\text { bottom trawling traces }\end{array}$ & 32 & 0.295 & 0.001 & 1.261 & -24.374 & 25 & 0.034 & 0.379 & & \\
\hline
\end{tabular}




\section{Appendix C}

Table A3. Determination coefficients $\left(\mathrm{R}^{2}\right)$, associated probability levels $(p)$, slopes, and intercepts of the simple linear regression models linking 95th percentile of Bottom Shear Stress (BSS) and one-year summed Bottom Trawling Effort (BTE) within cells containing sampled stations, and assessed parameters within the distal part of the WGMP. Adjusted determination coefficients $\left(\mathrm{R}^{2}\right)$ and associated probability levels $(p)$ of the multiple linear regression models linking the combination of BSS and BSS with assessed parameters within the distal part of the WGMP. Bold types are indicative of significant $(p<0.05)$ correlations and underlined types correspond to simple linear regression models without the outliers constituted by stations AN and 3_8.

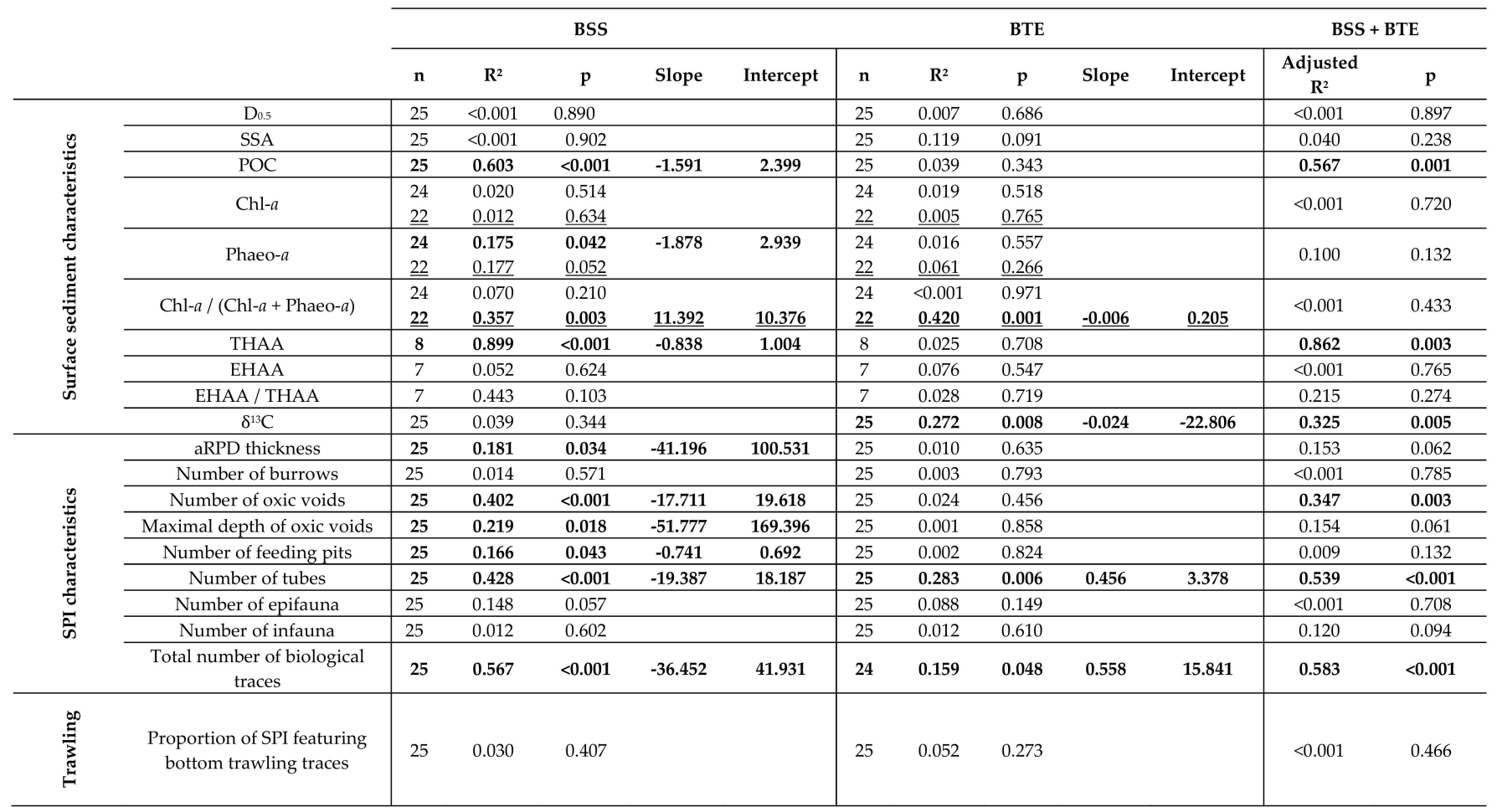

\section{References}

1. Aller, R.C. Mobile deltaic and continental shelf muds as suboxic, fluidized bed reactors. Mar. Chem. 1998, 61, 143-155. [CrossRef]

2. Burdige, D.J. Burial of terrestrial organic matter in marine sediments: A re-assessment. Glob. Biogeochem. Cycles 2005, 19, 1-7. [CrossRef]

3. Blair, N.E.; Aller, R.C. The fate of terrestrial organic carbon in the marine environment. Ann. Rev. Mar. Sci. $2012,4,401-423$. [CrossRef]

4. Meade, R.H. River-sediment inputs to major deltas. In Sea Level-Rise and Coastal Subsidence. Coastal Systems and Continental Margins; Miliman, J.D., Haq, B.U., Eds.; Springer: Dordrecht, The Netherlands, 1996; Volume 2, pp. 63-85. [CrossRef]

5. McKee, B.A.; Aller, R.C.; Allison, M.A.; Bianchi, T.S.; Kineke, G.C. Transport and transformation of dissolved and particulate materials on continental margins influenced by major rivers: Benthic boundary layer and seabed processes. Cont. Shelf Res. 2004, 24, 899-926. [CrossRef]

6. Hedges, J.I.; Keil, R.G. Sedimentary organic matter preservation: An assessment and speculative synthesis. Mar. Chem. 1995, 49, 81-115. [CrossRef]

7. Burdige, D.J. Estuarine and coastal sediments-Coupled biogeochemical cycling. In Treatise on Estuarine and Coastal Science; Wolanski, E., McLusky, D., Eds.; Academic Press: Cambridge, MA, USA, 2012; Volume 5, pp. 279-316. [CrossRef]

8. Kristensen, E.; Penha-Lopes, G.; Delefosse, M.; Valdemarsen, T.; Quintana, C.O.; Banta, G.T. What is bioturbation? The need for a precise definition for fauna in aquatic sciences. Mar. Ecol. Prog. Ser. 2012, 446, 285-302. [CrossRef]

9. Aller, R.C. The effects of macrobenthos on chemical properties of marine sediment and overlying water. In Animal-Sediment Relations; McCall, P.L., Tevesz, M.J.S., Eds.; Springer: Boston, MA, USA, 1982; Volume 100, pp. 53-102. [CrossRef]

10. Kristensen, E. Organic matter diagenesis at the oxic/anoxic interface in coastal marine sediments, with emphasis on the role of burrowing animals. Hydrobiologia 2000, 426, 1-24. [CrossRef]

11. Kristensen, E.; Kostka, J.E. Macrofaunal burrows and irrigation in marine sediment: Microbiological and biogeochemical interactions. In Interactions Between Macro- and Microorganisms in Marine Sediments; Kristensen, E., Haese, R.R., Kostka, J.E., Eds.; American Geophysical Union: Washington, DC, USA, 2013; pp. 125-157. [CrossRef] 
12. Rhoads, D.C.; Boesch, D.F.; Zhican, T.; Fengshan, X.; Liqiang, H.; Nilsen, K.J. Macrobenthos and sedimentary facies on the Changjiang delta platform and adjacent continental shelf, East China Sea. Cont. Shelf Res. 1985, 4, 189-213. [CrossRef]

13. Watling, L.; Norse, E.A. Disturbance of the seabed by mobile fishing gear: A comparison to forest clearcutting. Conserv. Biol. 1998, 12, 1180-1197. [CrossRef]

14. Durrieu De Madron, X.; Ferré, B.; Le Corre, G.; Grenz, C.; Conan, P.; Pujo-Pay, M.; Buscail, R.; Bodiot, O. Trawling-induced resuspension and dispersal of muddy sediments and dissolved elements in the Gulf of Lion (NW Mediterranean). Cont. Shelf Res. 2005, 25, 2387-2409. [CrossRef]

15. Ferré, B.; Durrieu de Madron, X.; Estournel, C.; Ulses, C.; Le Corre, G. Impact of natural (waves and currents) and anthropogenic (trawl) resuspension on the export of particulate matter to the open ocean. Application to the Gulf of Lion (NW Mediterranean). Cont. Shelf Res. 2008, 28, 2071-2091. [CrossRef]

16. Palanques, A.; Guillén, J.; Puig, P. Impact of bottom trawling on water turbidity and muddy sediment of an unfished continental shelf. Limnol. Oceanogr. 2001, 46, 1100-1110. [CrossRef]

17. Palanques, A.; Puig, P.; Guillén, J.; Demestre, M.; Martín, J. Effects of bottom trawling on the Ebro continental shelf sedimentary system (NW Mediterranean). Cont. Shelf Res. 2014, 72, 83-98. [CrossRef]

18. Oberle, F.K.J.; Storlazzi, C.D.; Hanebuth, T.J.J. What a drag: Quantifying the global impact of chronic bottom trawling on continental shelf sediment. J. Mar. Syst. 2016, 159, 109-119. [CrossRef]

19. Mengual, B.; Cayocca, F.; Le Hir, P.; Draye, R.; Laffargue, P.; Vincent, B.; Garlan, T. Influence of bottom trawling on sediment resuspension in the 'Grande-Vasière' area (Bay of Biscay, France). Ocean Dyn. 2016, 66, 1181-1207. [CrossRef]

20. Mengual, B.; Le Hir, P.; Cayocca, F.; Garlan, T. Bottom trawling contribution to the spatio-temporal variability of sediment fluxes on the continental shelf of the Bay of Biscay (France). Mar. Geol. 2019, 414, 77-91. [CrossRef]

21. Thrush, S.F.; Dayton, P.K. Disturbance to marine benthic habitats by trawling and dredging: Implications for marine biodiversity. Annu. Rev. Ecol. Syst. 2002, 33, 449-473. [CrossRef]

22. Thrush, S.F.; Gray, J.S.; Hewitt, J.E.; Ugland, K.I. Predicting the effects of habitat homogenization on marine biodiversity. Ecol. Appl. 2006, 16, 1636-1642. [CrossRef]

23. Kaiser, M.J.; Collie, J.S.; Hall, S.J.; Jennings, S.; Poiner, I.R. Modification of marine habitats by trawling activities: Prognosis and solutions. Fish Fish. 2002, 3, 114-136. [CrossRef]

24. Queirós, A.M.; Hiddink, J.G.; Kaiser, M.J.; Hinz, H. Effects of chronic bottom trawling disturbance on benthic biomass, production and size spectra in different habitats. J. Exp. Mar. Biol. Ecol. 2006, 335, 91-103. [CrossRef]

25. Lesueur, P.; Jouanneau, J.M.; Boust, D.; Tastet, J.P.; Weber, O. Sedimentation rates and fluxes in the continental shelf mud fields in the Bay of Biscay (France). Cont. Shelf Res. 2001, 21, 1383-1401. [CrossRef]

26. Lesueur, P.; Tastet, J.P.; Weber, O. Origin and morphosedimentary evolution of fine-grained modern continental shelf deposits: The Gironde mud fields (Bay of Biscay, France). Sedimentology 2002, 49, 1299-1320. [CrossRef]

27. Doxaran, D.; Froidefond, J.M.; Castaing, P.; Babin, M. Dynamics of the turbidity maximum zone in a macrotidal estuary (the Gironde, France): Observations from field and MODIS satellite data. Estuar. Coast. Shelf Sci. 2009, 81, 321-332. [CrossRef]

28. Constantin, S.; Doxaran, D.; Derkacheva, A.; Novoa, S.; Lavigne, H. Multi-temporal dynamics of suspended particulate matter in a macro-tidal river Plume (the Gironde) as observed by satellite data. Estuar. Coast. Shelf Sci. 2018, 202, 172-184. [CrossRef]

29. Etcheber, H.; Schmidt, S.; Sottolichio, A.; Maneux, E.; Chabaux, G.; Escalier, J.M.; Wennekes, H.; Derriennic, H.; Schmeltz, M.; Quéméner, L.; et al. Monitoring water quality in estuarine environments: Lessons from the MAGEST monitoring program in the Gironde fluvial-estuarine system. Hydrol. Earth Syst. Sci. 2011, 15, 831-840. [CrossRef]

30. Cirac, P.; Berne, S.; Castaing, P.; Weber, O. Processus de mise en place et d'évolution de la couverture sédimentaire superficielle de la plate-forme nord-aquitaine. Oceanol. Acta 2000, 23, 663-686. [CrossRef]

31. Castaing, P.; Allen, G.P. Mechanisms controlling seaward escape of suspended sediment from the Gironde: A macrotidal estuary in France. Mar. Geol. 1981, 40, 101-118. [CrossRef]

32. Castaing, P.; Allen, G.; Houdart, M.; Moign, Y. Étude par télédétection de la dispersion en mer des eaux estuariennes issues de la Gironde et du Pertuis de Maumusson. Oceanol. Acta 1979, 2, 459-469.

33. Castaing, P.; Philipps, I.; Weber, O. Répartition et dispersion des suspensions dans les eaux du plateau continental aquitain. Oceanol. Acta 1982, 5, 85-96.

34. Longère, P.; Dorel, D. Etude des sédiments meubles de la vasière de la Gironde et des régions avoisinantes. Rev. des Trav. l'Institut des Pêches Marit. 1970, 34, 233-256.

35. Jouanneau, J.M.; Weber, O.; Latouche, C.; Vernet, J.P.; Dominik, J. Erosion, non-deposition and sedimentary processes through a sedimentological and radioisotopic study of surficial deposits from the "Ouest-Gironde vasière" (Bay of Biscay). Cont. Shelf Res. 1989, 9, 325-342. [CrossRef]

36. Weber, O.; Jouanneau, J.M.; Ruch, P.; Mirmand, M. Grain-size relationship between suspended matter originating in the Gironde estuary and shelf mud-patch deposits. Mar. Geol. 1991, 96, 159-165. [CrossRef]

37. Lesueur, P.; Tastet, J.P. Les Vasières de plate-forme du Golfe de Gascogne (France). Actes du III Colloque International « Océanographie du Golfe de Gascogne » 1993, 181-184.

38. Lesueur, P.; Tastet, J.P. Facies, internal structures and sequences of modern Gironde-derived muds on the Aquitaine inner shelf, France. Mar. Geol. 1994, 120, 267-290. [CrossRef] 
39. Gadel, F.; Jouanneau, J.M.; Weber, O.; Serve, L.; Comellas, L. Traceurs organiques dans les dépôts de la vasière Ouest-Gironde (Golfe de Gascogne). Oceanol. Acta 1997, 20, 687-695.

40. Parra, M.; Castaing, P.; Jouanneau, J.M.; Grousset, F.; Latouche, C. Nd-Sr isotopic composition of present-day sediments from the Gironde Estuary, its draining basins and the WestGironde mud patch (SW France). Cont. Shelf Res. 1998, 19, 135-150. [CrossRef]

41. Lesueur, P.; Weber, O.; Marambat, L.; Tastet, J.P.; Jouanneau, J.M.; Turon, J.L. Datation d'une vasière de plateforme atlantique au débouché d'un estuaire: La vasière à l'ouest de la Gironde (France) est d'âge historique (VIème siècle à nos jours). Comptes rendus l'Académie des Sci. Série 2 1989, 308, 935-940.

42. Lesueur, P.; Tastet, J.P.; Weber, O.; Sinko, J.A. Modèle faciologique d'un corps sédimentaire pélitique de plate-forme la vasière Ouest-Gironde (France). Oceanol. Acta 1991, 11, 143-153.

43. Lesueur, P.; Tastet, J.P.; Marambat, L. Shelf mud fields formation within historical times: Examples from offshore the Gironde estuary, France. Cont. Shelf Res. 1996, 16, 1849-1870. [CrossRef]

44. Relexans, J.C.; Lin, R.G.; Castel, J.; Etcheber, H.; Laborde, P. Response of biota to sedimentary organic matter quality of the west Gironde mud patch, Bay of Biscay (France). Oceanol. Acta 1992, 15, 639-649.

45. Massé, C.; Meisterhans, G.; Deflandre, B.; Bachelet, G.; Bourasseau, L.; Bichon, S.; Ciutat, A.; Jude-Lemeilleur, F.; Lavesque, N.; Raymond, N.; et al. Bacterial and macrofaunal communities in the sediments of the West Gironde Mud Patch, Bay of Biscay (France). Estuar. Coast. Shelf Sci. 2016, 179, 189-200. [CrossRef]

46. Système d'Informations Halieutiques Ifremer. In Activité des navires de pêche région Nouvelle-Aquitaine; Ifremer: Paris, France, 2017.

47. Lesueur, P. Les Vasières de la Plate-Forme Ouest Gironde (France): Modèle Faciologique Et Archive Sédimentaire Des Flux Côtiers. Ph.D. Thesis, Université Bordeaux 1, Talence, France, 19 October 1992.

48. Gillet, H.; Deflandre, B. JERICOBENT-5-TH cruise, RV Thalia; Université de Bordeaux: Bordeaux, France, 2018. [CrossRef]

49. Schmidt, S.; Deflandre, B. JERICOBENT-5 cruise, RV Côtes De La Manche; Université de Bordeaux: Bordeaux, France, 2018. [CrossRef]

50. Mayer, L.M. Surface area control of organic carbon accumulation in continental shelf sediments. Geochim. Cosmochim. Acta 1994, 58, 1271-1284. [CrossRef]

51. Migeon, S.; Weber, O.; Faugeres, J.C.; Saint-Paul, J. SCOPIX: A new X-ray imaging system for core analysis. Geo-Mar. Lett. 1999, 18, 251-255. [CrossRef]

52. Rhoads, D.C.; Germano, J.D. Characterization of organism-sediment relations using sediment profile imaging: An efficient method of remote ecological monitoring of the seafloor (Remots System). Mar. Ecol. Prog. Ser. 1982, 8, 115-128. [CrossRef]

53. Etcheber, H.; Relexans, J.C.; Beliard, M.; Weber, O.; Buscail, R.; Heussner, S. Distribution and quality of sedimentary organic matter on the Aquitanian margin (Bay of Biscay). Deep. Res. Part II 1999, 46, 2249-2288. [CrossRef]

54. Mayer, L.M.; Schick, L.L.; Sawyer, T.; Plante, C.J.; Jumars, P.A.; Self, R.L. Bioavailable amino acids in sediments: A biomimetic, kinetics based approach. Limnol. Oceanogr. 1995, 40, 511-520. [CrossRef]

55. Pastor, L.; Deflandre, B.; Viollier, E.; Cathalot, C.; Metzger, E.; Rabouille, C.; Escoubeyrou, K.; Lloret, E.; Pruski, A.M.; Vétion, G.; et al. Influence of the organic matter composition on benthic oxygen demand in the Rhône River prodelta (NW Mediterranean Sea). Cont. Shelf Res. 2011, 31, 1008-1019. [CrossRef]

56. Bonifácio, P.; Bourgeois, S.; Labrune, C.; Amouroux, J.M.; Escoubeyrou, K.; Buscail, R.; Romero-Ramirez, A.; Lantoine, F.; Vétion, G.; Bichon, S.; et al. Spatiotemporal changes in surface sediment characteristics and benthic macrofauna composition off the Rhône River in relation to its hydrological regime. Estuar. Coast. Shelf Sci. 2014, 151, 196-209. [CrossRef]

57. Wakeham, S.G.; Lee, C.; Hedges, J.I.; Hernes, P.J.; Peterson, M.L. Molecular indicators of diagenetic status in marine organic matter. Geochim. Cosmochim. Acta 1997, 61, 5363-5369. [CrossRef]

58. Neveux, J.; Lantoine, F. Spectrofluorometric assay of chlorophylls and phaeopigments using the least squares approximation technique. Deep. Res. Part I 1993, 40, 1747-1765. [CrossRef]

59. Coplen, T.B. Guidelines and recommended terms for expression of stable- isotope-ratio and gas-ratio measurement results. Rapid Commun. Mass Spectrom 2011, 25, 2538-2560. [CrossRef] [PubMed]

60. Romero-Ramirez, A.; Grémare, A.; Desmalades, M.; Duchêne, J.C. Semi-automatic analysis and interpretation of sediment profile images. Environ. Model. Softw. 2013, 47, 42-54. [CrossRef]

61. Rosenberg, R.; Grémare, A.; Amouroux, J.M.; Nilsson, H.C. Benthic habitats in the northwest Mediterranean characterised by sedimentary organics, benthic macrofauna and sediment profile images. Estuar. Coast. Shelf Sci. 2003, 57, 297-311. [CrossRef]

62. Rosenberg, R.; Nilsson, H.C.; Grémare, A.; Amouroux, J.M. Effects of demersal trawling on marine sedimentary habitats analysed by sediment profile imagery. J. Exp. Mar. Biol. Ecol. 2003, 285-286, 465-477. [CrossRef]

63. Germano, J.D.; Rhoads, D.C.; Valente, R.M.; Carey, D.A.; Solan, M. The use of sediment profile imaging (SPI) for environmental impact assessments and monitoring studies: Lessons learned from the past four decades. Oceanogr. Mar. Biol. Annu. Rev. 2011, 49, 235-298. [CrossRef]

64. Diaz, M.; Grasso, F.; Le Hir, P.; Sottolichio, A.; Caillaud, M.; Thouvenin, B. Modeling mud and sand transfers between a macrotidal estuary and the continental shelf: Influence of the sediment transport parameterization. J. Geophys. Res. Oceans 2020, 125, e2019JC015643. [CrossRef]

65. Lazure, P.; Dumas, F. An external-internal mode coupling for a 3D hydrodynamical model for applications at regional scale (MARS). Adv. Water Resour. 2008, 31, 233-250. [CrossRef] 
66. Roland, A.; Ardhuin, F. On the developments of spectral wave models: Numerics and parameterizations for the coastal ocean. Ocean Dyn. 2014, 64, 833-846. [CrossRef]

67. Soulsby, R. Dynamics of Marine Sands: A Manual for Practical Applications; Inst of Civil Engineers Pub: London, UK, 1997.

68. Grasso, F.; Verney, R.; Le Hir, P.; Thouvenin, B.; Schulz, E.; Kervella, Y.; Khojasteh Pour Fard, I.; Lemoine, J.P.; Dumas, F.; Garnier, V. Suspended sediment dynamics in the macrotidal seine estuary (France)-Part 1: Numerical modeling of turbidity maximum dynamics. J. Geophys. Res. Oceans 2008, 123, 558-577. [CrossRef]

69. Global Fishing Watch. Available online: https://globalfishingwatch.org (accessed on 13 March 2019).

70. Kroodsma, D.A.; Mayorga, J.; Hochberg, T.; Miller, N.A.; Boerder, K.; Ferretti, F.; Wilson, A.; Bergman, B.; White, T.D.; Block, B.A.; et al. Tracking the global footprint of fisheries. Science 2018, 359, 904-908. [CrossRef]

71. Clarke, K.R.; Somerfield, P.J.; Gorley, R.N. Testing of null hypotheses in exploratory community analyses: Similarity profiles and biota-environment linkage. J. Exp. Mar. Biol. Ecol. 2008, 366, 56-69. [CrossRef]

72. Clarke, K.R. Non-parametric multivariate analyses of changes in community structure. Aust. J. Ecol. 1993, 18, 117-143. [CrossRef]

73. Clarke, K.R.; Warwick, R.M. Change in Marine Communities: An Approach to Statistical Analysis and Interpretation, 2nd ed.; PRIMER-E: Plymouth, UK, 2001.

74. Lansard, B.; Rabouille, C.; Denis, L.; Grenz, C. Benthic remineralization at the land-ocean interface: A case study of the Rhône River (NW Mediterranean Sea). Estuar. Coast. Shelf Sci. 2009, 81, 544-554. [CrossRef]

75. Antonelli, C.; Eyrolle, F.; Rolland, B.; Provansal, M.; Sabatier, F. Suspended sediment and 137Cs fluxes during the exceptional December 2003 flood in the Rhone River, southeast France. Geomorphology 2008, 95, 350-360. [CrossRef]

76. Touzani, A.; Giresse, P. The Rhone River prodelta: Short-term (100-103 year) sedimentation patterns and human impact. J. Coast. Res. 2002, 18, 102-117.

77. Marion, C.; Dufois, F.; Arnaud, M.; Vella, C. In situ record of sedimentary processes near the Rhône River mouth during winter events (Gulf of Lions, Mediterranean Sea). Cont. Shelf Res. 2010, 30, 1095-1107. [CrossRef]

78. Dufois, F.; Verney, R.; Le Hir, P.; Dumas, F.; Charmasson, S. Impact of winter storms on sediment erosion in the Rhone River prodelta and fate of sediment in the Gulf of Lions (North Western Mediterranean Sea). Cont. Shelf Res. 2014, 72, 57-72. [CrossRef]

79. Calmet, D.; Fernandez, J. Caesium distribution in northwest Mediterranean seawater, suspended particles and sediments. Cont. Shelf Res. 1990, 10, 895-913. [CrossRef]

80. Charmasson, S.; Radakovitch, O.; Arnaud, M.; Bouisset, P.; Pruchon, A.S. Long-core profiles of 137Cs, 134Cs, 60Co and 210Pb in sediment near the Rhone River (northwestern Meiterranean Sea). Estuaries 1998, 21, 367-378. [CrossRef]

81. Bourgeois, S.; Pruski, A.M.; Sun, M.Y.; Buscail, R.; Lantoine, F.; Kerhervé, P.; Vétion, G.; Rivière, B.; Charles, F. Distribution and lability of land-derived organic matter in the surface sediments of the Rhône prodelta and the adjacent shelf (Mediterranean Sea, France): A multi proxy study. Biogeosciences 2011, 8, 3107-3125. [CrossRef]

82. Labrune, C.; Romero-Ramirez, A.; Amouroux, J.M.; Duchêne, J.C.; Desmalades, M.; Escoubeyrou, K.; Buscail, R.; Grémare, A. Comparison of ecological quality indices based on benthic macrofauna and sediment profile images: A case study along an organic enrichment gradient off the Rhône River. Ecol. Indic. 2012, 12, 133-142. [CrossRef]

83. Kaiser, M.J.; Clarke, K.R.; Hinz, H.; Austen, M.C.V.; Somerfield, P.J.; Karakassis, I. Global analysis of response and recovery of benthic biota to fishing. Mar. Ecol. Prog. Ser. 2006, 311, 1-14. [CrossRef]

84. Sciberras, M.; Geert, J.; Simon, H.; Szostek, C.L.; Hughes, K.M.; Kneafsey, B.; Clarke, L.J.; Ellis, N.; Rijnsdorp, A.D.; McConnaughey, R.A.; et al. Response of benthic fauna to experimental bottom fishing: A global meta-analysis. Fish Fish. 2018, 19, 698-715. [CrossRef]

85. Dufois, F.; Garreau, P.; Le Hir, P.; Forget, P. Wave-and current-induced bottom shear stress distribution in the Gulf of Lions. Cont. Shelf Res. 2008, 28, 1920-1934. [CrossRef]

86. Kaiser, M.J.; Spencer, B.E. The effects of beam-trawl disturbance on infaunal communities in different habitats. J. Anim. Ecol. 1996, 65, 348-358. [CrossRef]

87. Smith, C.J.; Banks, A.C.; Papadopoulou, K.N. Improving the quantitative estimation of trawling impacts from sidescan-sonar and underwater-video imagery. ICES J. Mar. Sci. 2007, 64, 1692-1701. [CrossRef]

88. Olsgard, F.; Schaanning, M.T.; Widdicombe, S.; Kendall, M.A.; Austen, M.C. Effects of bottom trawling on ecosystem functioning. J. Exp. Mar. Biol. Ecol. 2008, 366, 123-133. [CrossRef]

89. De Juan, S.; Demestre, M.; Sánchez, P. Exploring the degree of trawling disturbance by the analysis of benthic communities ranging from a heavily exploited fishing ground to an undisturbed area in the NW Mediterranean. Sci. Mar. 2011, 75, 507-516. [CrossRef]

90. Widdicombe, S.; Austen, M.C. The interaction between physical disturbance and organic enrichment: An important element in structuring benthic communities. Limnol. Oceanogr. 2001, 46, 1720-1733. [CrossRef]

91. Selby, I.; Evans, N.C. Origins of mud clasts and suspensions on the seabed in Hong Kong. Cont. Shelf Res. 1997, 17, 57-78. [CrossRef]

92. Fettweis, M.; Du Four, I.; Zeelmaekers, E.; Baeteman, C.; Francken, F.; Houziaux, J.-S.; Mathys, M.; Nechad, B.; Pison, V.; Vandenberghe, N.; et al. Mud Origin, Characterisation and Human Activities (MOCHA): Final Report; Belgian Science Policy Office: Brussels, Belgium, 2007.

93. Grémare, A.; (Université de Bordeaux, Talence, France). Personal communication, 2020. 
94. Nilsson, H.C.; Rosenberg, R. Effects on marine sedimentary habitats of experimental trawling analysed by sediment profile imagery. J. Exp. Mar. Biol. Ecol. 2003, 285-286, 453-463. [CrossRef]

95. Smith, C.J.; Rumohr, H.; Karakassis, I.; Papadopoulou, K.N. Analysing the impact of bottom trawls on sedimentary seabeds with sediment profile imagery. J. Exp. Mar. Biol. Ecol. 2003, 285-286, 479-496. [CrossRef]

96. Tiano, J.C.; Van Der Reijden, K.J.; O’Flynn, S.; Beauchard, O.; Van Der Ree, S.; Van Der Wees, J.; Ysebaert, T.; Soetaert, K. Experimental bottom trawling finds resilience in large-bodied infauna but vulnerability for epifauna and juveniles in the Frisian Front. Mar. Environ. Res. 2020, 159, 104964. [CrossRef]

97. Darnaude, A.M.; Salen-Picard, C.; Harmelin-Vivien, M.L. Depth variation in terrestrial particulate organic matter exploitation by marine coastal benthic communities off the Rhone River delta (NW Mediterranean). Mar. Ecol. Prog. Ser. 2004, $275,47-57$. [CrossRef]

98. Tesi, T.; Miserocchi, S.; Goñi, M.A.; Langone, L. Source, transport and fate of terrestrial organic carbon on the western Mediterranean Sea, Gulf of Lions, France. Mar. Chem. 2007, 105, 101-117. [CrossRef]

99. Cathalot, C.; Rabouille, C.; Tisnérat-Laborde, N.; Toussaint, F.; Kerhervé, P.; Buscail, R.; Loftis, K.; Sun, M.Y.; Tronczynski, J.; Azoury, S.; et al. The fate of river organic carbon in coastal areas: A study in the Rhône River delta using multiple isotopic ( $\delta 13 \mathrm{C}$, 814C) and organic tracers. Geochim. Cosmochim. Acta 2013, 118, 33-55. [CrossRef]

100. Fontugne, M.R.; Jouanneau, J.M. Modulation of the particulate organic carbon flux to the ocean by a macrotidal estuary: Evidence from measurements of carbon isotopes in organic matter from the Gironde system. Estuar. Coast. Shelf Sci. 1987, $24,377-387$. [CrossRef]

101. Middelburg, J.J.; Herman, P.M.J. Organic matter processing in tidal estuaries. Mar. Chem. 2007, 106, 127-147. [CrossRef]

102. Savoye, N.; David, V.; Morisseau, F.; Etcheber, H.; Abril, G.; Billy, I.; Charlier, K.; Oggian, G.; Derriennic, H.; Sautour, B. Origin and composition of particulate organic matter in a macrotidal turbid estuary: The Gironde Estuary, France. Estuar. Coast. Shelf Sci. 2012, 108, 16-28. [CrossRef]

103. Sottolichio, A.; Castaing, P. A synthesis on seasonal dynamics of highly-concentrated structures in the Gironde estuary. Earth Planet. Sci. 1999, 329, 795-800. [CrossRef]

104. Jouanneau, J.M.; Latouche, C. The Gironde Estuary; Schweizerbart Science Publishers: Stuttgart, Germany, 1981.

105. Etcheber, H.; Taillez, A.; Abril, G.; Garnier, J.; Servais, P.; Moatar, F.; Commarieu, M.V. Particulate organic carbon in the estuarine turbidity maxima of the Gironde, Loire and Seine estuaries: Origin and lability. Hydrobiologia 2007, 588, 245-259. [CrossRef]

106. Ulses, C.; Estournel, C.; Durrieu de Madron, X.; Palanques, A. Suspended sediment transport in the Gulf of Lions (NW Mediterranean): Impact of extreme storms and floods. Cont. Shelf Res. 2008, 28, 2048-2070. [CrossRef]

107. Mayer, L.M.; Jumars, P.A.; Taghon, G.L.; Macko, S.A.; Trumbore, S. Low-density particles as potential nitrogenous foods for benthos. J. Mar. Res. 1993, 51, 373-389. [CrossRef]

108. Abril, G.; Etcheber, H.; Le Hir, P.; Bassoullet, P.; Boutier, B.; Frankignoulle, M. Oxic/anoxic oscillations and organic carbon mineralization in an estuarine maximum turbidity zone (The Gironde, France). Limnol. Oceanogr. 1999, 44, 1304-1315. [CrossRef]

109. Abril, G.; Nogueira, M.; Etcheber, H.; Cabeçadas, G.; Lemaire, E.; Brogueira, M.J. Behaviour of organic carbon in nine contrasting European estuaries. Estuar. Coast. Shelf Sci. 2002, 54, 241-262. [CrossRef]

110. Lemaire, E.; Abril, G.; De Wit, R.; Etcheber, H. Effect of turbidity on phytoplanktonic pigments degradation in the Gironde Estuary. Comptes Rendus Geosci. 2002, 334, 251-258. [CrossRef]

111. Pearson, T.H.; Rosenberg, R. Macrobenthos succession in relation to organic enrichment and pollution of the marine environment. Oceanogr. Mar. Biol. Annu. Rev. 1978, 16, 229-331.

112. Miralles, J.; Arnaud, M.; Radakovitch, O.; Marion, C.; Cagnat, X. Radionuclide deposition in the Rhône River Prodelta (NW Mediterranean sea) in response to the December 2003 extreme flood. Mar. Geol. 2006, 234, 179-189. [CrossRef]

113. Salen-Picard, C.; Darnaude, A.M.; Arlhac, D.; Harmelin-Vivien, M.L. Fluctuations of macrobenthic populations: A link between climate-driven river run-off and sole fishery yields in the Gulf of Lions. Oecologia 2002, 133, 380-388. [CrossRef]

114. Miralles, J.; Radakovitch, O.; Aloisi, J.C. 210Pb sedimentation rates from the Northwestern Mediterranean margin. Mar. Geol. 2005, 216, 155-167. [CrossRef]

115. Zuo, Z.; Eisma, D.; Berger, G.W. Determination of sediment accumulation and mixing rates in the Gulf of Lions, Mediterranean Sea. Oceanol. Acta 1991, 14, 253-262.

116. Dorgan, K.M.; Jumars, P.A.; Johnson, B.D.; Boudreau, B.P. Macrofaunal burrowing: The medium is the message. Oceanogr. Mar. Biol. 2006, 44, 85-121.

117. Lamarque, B.; Deflandre, B.; Galindo Dalto, A.; Schmidt, S.; Romero-Ramirez, A.; Garabetian, F.; Dubosq, N.; Diaz, M.; Grasso, F.; Sottolichio, A.; et al. Spatial Distributions of Surface Sedimentary Organics and Sediment Profile Image Characteristics in a High-Energy Temperate Marine RiOMar: The West Gironde Mud Patch; SEANOE. 2021. Available online: http://b2find.eudat. eu/dataset/e591e5d7-3dbc-57bc-9588-532deed0a3c2 (accessed on 1 February 2021). 